\title{
The Maiden of Orleans
}

A Romantic Tragedy

Friedrich Schiller translated by John T. Krumpelmann 
The Maiden of Orleans 


\section{IIIIUNC}

From 1949 to 2004, UNC Press and the UNC Department of Germanic \& Slavic Languages and Literatures published the UNC Studies in the Germanic Languages and Literatures series. Monographs, anthologies, and critical editions in the series covered an array of topics including medieval and modern literature, theater, linguistics, philology, onomastics, and the history of ideas. Through the generous support of the National Endowment for the Humanities and the Andrew W. Mellon Foundation, books in the series have been reissued in new paperback and open access digital editions. For a complete list of books visit www.uncpress.org. 


\section{The Maiden of Orleans}

\section{A Romantic Tragedy}

Second Edition

JOHANN CHRISTOPH FRIEDRICH VON SCHILLER

TRANSLATED BY JOHN T. KRUMPELMANN

UNC Studies in the Germanic Languages and Literatures

Number 37 
Copyright (C) 1962

This work is licensed under a Creative Commons CC BY-NC-ND license. To view a copy of the license, visit http://creativecommons. org/licenses.

Suggested citation: Schiller, Friedrich von. The Maiden of Orleans: A Romantic Tragedy. Translated by John T. Krumpelmann. Chapel Hill: University of North Carolina Press, 1962. DOI: https://doi. org/10.5149/9781469657721_FriedrichSchiller

Library of Congress Cataloging-in-Publication Data

Names: Krumpelmann, John T.

Title: The Maiden of Orleans : A romantic tragedy / by John T. Krumpelmann.

Other titles: University of North Carolina Studies in the Germanic Languages and Literatures ; no. 37.

Description: Chapel Hill : University of North Carolina Press, [1962] Series: University of North Carolina Studies in the Germanic Languages and Literatures.

Identifiers: LCCN 63062703 | ISBN 978-1-4696-5771-4 (pbk: alk. paper) | ISBN 978-1-4696-5772-1 (ebook)

Subjects: Joan, of Arc, Saint, 1412-1431 — Drama.

Classification: LCC PD25 .N6 NO. 37 | DCC 832/.6 


To the Memory of my Mother

MARIE LOUISE BERNARD KRUMPELMANN NEW ORLEANS

1865-1921 


\section{PREFACE}

The activities in 1949, commemorative of the Bicentennial of the birth of Johann Wolfgang Goethe, seemed to presage a similar display of devotion to the memory of Johann Christoph Friedrich Schiller in the observation of the two hundredth anniversary of his birth in 1959. The centennial anniversary of Schiller's birth in 1859 witnessed a more spontaneous and widespread demonstration of devotion to the German poet of youth and democracy than had been manifested for Goethe's memory in the centenary of his natal year.

Present indications fail to confirm the validity of the prediction. Many forces have contributed to this change in worldattitude towards the two leading poets of Germany. The first centennial of Goethe's birth arrived only some seventeen years after his death. Since that year marked the flood tide of revolution in Europe, the public had not yet come to appreciate the placidity of the Olympian aristocrat Goethe who had never been a popular personality in his lifetime or in posterity. However, when the centenary of Schiller's natal year arrived, the spirit of the revolution, although politically suppressed, was still alive, and youth was still idealistic in its enthusiasm for democracy.

In 1949 the world celebrated the world-figure, the protagonist of World Literature, the Jovian Goethe. In the century which intervened between 1849 and 1949 Goethe's masterpiece, Faust, at first regarded as immoral, had become immortal. Now, ten years later, it seems impossible to expect the world to enthuse for the author of "Das Ideal und das Leben," for the poet who lent fame to such democratic revolutionists as Wilhelm Tell, Don Carlos and Jeanne D'Arc, and who, dramatically at least, championed the cause of Mary Stuart against Queen Elizabeth of England. The ideal of democracy has, as must all ideals, ceased with the attainment of its goal. The youth are no longer young idealists, but actualists, who live rather in the facts of today than in the fictions of tomorrow. For them democracy is no longer arrayed in a roseate nimbus of fantasy. Since at least two generations have lived and died for the "ideal" of making the world safe for democracy, it is not to be expected that the youth of today can be too enthusiastic about Schiller, who always created his characters out of idealistic concepts.

After witnessing the solemn tribute paid to Goethe in his native Frankfurt in August, 1949, the present writer resolved 
that his native New Orleans might offer no more fitting homage to Schiller in 1959 than to present an American translation of his Jungfrau von Orleans, especially since Voltaire's "La Pucelle," the "Joan la Pucelle" of Shakespeare, has since become the "Johanna" of Schiller's drama, the protogée of the quasiOrleanian, the Iconoclastic Mark Twain, and eventually, the "Sancta Joanna" of the Roman Catholic Church.

The present translation, the result of three renderings completed on December 30, 1951, October 8, 1956 and December 13,1957 , is a labor of love which lays no claim to merit beyond that of an earnest effort to bring to the English reader in his own language the sympathetic poetical romanticism with which the German Protestant poet Schiller clothed the poor peasant girl of Lorraine more than a century before the Catholic Church formally decreed her sainthood.

Striving after a faithful reproduction of the drama in a foreign but kindred tongue, the translator has attempted to preserve the idiosyncrasies of the poet and his age. To this end he has adopted the theory of translation enunciated by Bayard Taylor in the preface to his most successful rendition of Goethe's Faust and practiced in that rendition. Taylor quotes Goethe: "There are two maxims of translation, the one requires that the author, of a foreign nation, be brought to us in such a manner that we may regard him as our own; the other, on the contrary, demands of us that we transport ourselves over to him, and adopt his situation, his mode of speaking and his peculiarities." Then Taylor queries: "Where the two languages are kindred, and equally capable of all varieties of metrical expression, may not both of these maxims be observed in the same translation?"

Taylor further observes that "in all discussions upon this subject the capacities of the English language have received but scanty justice" (xii) and that "certain affinities between the two languages have not been properly considered" (xiii). [see my Bayard Taylor and German Letters, Hamburg, Cram, De Gruyter, 1959.]

The present translator has also kept in mind Goethe's words in the "Noten und Abhandlungen" to his West-östlicher Divan: "So we experienced the third epoch, which can be called the highest and final one, namely that one where one would like to make the translation identical with the original, so that it might be considered not a substitute for the original but might take its place.

"This type [of translation] at first met with the greatest 
opposition, for the translator who adheres firmly to the original gives up more or less the originality of his nation, and thus there arises a third creation to which the taste of the populace must gradually be elevated."

Like Taylor I too have given proper consideration to the affinities existing between the genius of the German language and that of ours, and have tried to do justice to the capacity of the English language. That I, like Taylor and all other translators, have failed to attain the impossible, a perfect translation, is admitted a priori.

I have consulted the standard English translation of this drama, that of Anna Swanwick, made over a century ago, and have, in a few cases, availed myself of assistance therefrom. Much general assistance has accrued to me from my long acquaintance with the school edition of the drama authored by my friend and former colleague, Roe-Merrill S. Heffner (Wisconsin).

To my present colleague, Professor Carl Hammer, Jr., I am indebted for his painstaking reading of the proof sheets and for valuable advice on points of usage. Likewise to Professor Frederic E. Coenen I express my appreciation for kindly criticism and for assistance in seeing this volume through the press. To the Staff of the Graduate School of Louisiana State University, I am grateful for the typing of the manuscript.

The translator alone has been responsible for all final decisions and, therefore, he alone is responsible for all the inadequacies which such a work as this must inevitably contain.

Baton Rouge

John T. Krumpelmann

April, 1959 


\section{FOREWORD TO THE NEW AND REVISED EDITION}

Since the demand has already exhausted the first printing of this translation, we offer a new and revised edition to supply future needs. The translator has taken this opportunity to correct the few typographical errors which intruded themselves into the original edition, to make certain improvements which he deems desirable in the punctuation, the diction and the meter of that edition, to accept some few suggestions for the amelioration of some renditions suggested by kindly and erudite critics. Other suggestions, though appreciated, were deemed too restrictive to the potentialities of the English language. Some were amusing, others, impossible.

Knowing that no translation of a poetic composition can ever be perfect, this translator accepts the principle enunciated by Bayard Taylor concerning his American rendering of Goethe's Faust, "in the original meters," and is eager to receive suggestions for improvement until all possible errors are eliminated. With these words we humbly submit this judicious and circumspect revision to the court of final appeal, the dictum of the reading public.

John T. Krumpelmann

Baton Rouge, Louisiana

March, 1962 


\section{DRAMATIS PERSONAE}

Charles the Seventh, King of France

QUEEN ISABEAU, his Mother

AGNES SOREL, his Beloved

PHILIP, THE GoOD, Duke of Burgundy

CounT DunoIs, Bastard of Orleans

LA Hire

DU CHATEL $\}$ royal officers

ARCHBISHOP OF RHEIMS

ChATILlON, a Burgundian Knight

RAOUL, a Knight of Lorraine

TALBOT, an English General

$\left.\begin{array}{l}\text { LIONEL } \\ \text { FASTOLF }\end{array}\right\}$ English officers

MONTGOMERY, a Welshman

COUNCILMEN OF ORLEANS

AN ENGLISH HERALD

THIBAUT D'ARC, a wealthy Countryman

MARGOT

LOUISON

JOHANNA

his Daughters

ETIENNE

Claude Marie their Suitors

RAIMOND

BERTRAND, another Countryman

THE APPARITION OF A BLACK KNIGHT

ChARCOAL-BURNER AND HIS WIFE

Soldiers AND PeOPle. Royal Servants-of-the-Crown, Bishops, Monks, Marshals, Magistrates, Courtiers and other mute persons in the train of the Coronation Procession. 


\section{PROLOGUE}

A rural Region. Right front, an image of a saint in a shrine; to the left a tall oak.

\section{FIRST SCENE}

Thibaut D'Arc. His three daughters. Three young shepherds, their suitors.

\section{THIBAUT}

Yea, my dear neighbors! Still today we are

True Frenchmen; still, free citizens and masters

Of this old sod, which once our fathers plowed.

Who knows who will rule over us tomorrow?

For everywhere the Englishman unfurls

His triumph-covered banner, while his steeds

Are trampling down the blooming fields of France.

Already Paris has proclaimed him victor,

And with the ancient crown of Dagobert

Adorns the scion of a foreign stem.

The offspring of our native kings must wander

Through his own realm in fight and dispossessed.

Against him in the hostile army fights

His closest cousin and his foremost peer;

Yea, his own raven-mother leads them on.

Around burn villages and towns. And near

And nearer rolls the smoke of devastation

Into these vales, which stiil repose in peace.

And so, dear neighbors, I've resolved 'fore God,

Since I today yet have it in my power,

To have my daughters cared for; for a woman,

Amid the woes of war, needs a protector;

And true love helps to lighten every burden.

(To the first Shepherd.)

Come here, Etienne! You woo my daughter Margot.

Our fields are bound together like good neighbors.

Your loving hearts are well attuned-that yields

A happy wedlock!

(To the Second.)

Claude Marie! You mum?

And my Louison casts her glances earthward?

Shall I divorce two hearts that found each other, 
Because you have not troves to offer me?

Who now has treasures? House and barns alike

Are both the prey of nearby foe and fire.

The loyal heart of the good spouse alone

Is storm-fast shelter in such times as these.

My father!

LOUISON

Claude Marie

My dear Louison!

LoUISON (embracing Johanna)

Dearest sister!

THIBAUT

I'll give each daughter thirty acres land, And stall and house and then a herd. For God Blessed me, and so may he bless also you.

MARGOT (embracing Johanna)

0 gladden father! Follow our example!

So let this day conclude three happy unions!

\section{THIBAUT}

Go! Make your plans! Tomorrow is the wedding.

I want the town-folk all to join the feast. (The two couples leave the stage arm in arm.)

\section{SECOND SCENE}

Thibaut. Raimond. Johanna.

\section{THIBAUT}

Jeanette, thy sisters now are going to marry.

I see them happy; they make glad my age.

But thou, my youngest, giv'st me grief and pain.

\section{RAIMOND}

What troubles you? Why do you scold your daughter?

THIBAUT

This honest lad, with whom no other here

In all the village can compare, the choicest,

He has to thee directed his affections,

And woos for thee, already the third harvest,

With quiet wish and heartfelt perseverance;

But thou dost, cold and resolute, reject him.

And yet not one of all the other shepherds

Can win from thee one friendly little smile. 
I see thee in full splendor of thy youth;

Thy Spring has come; it is the time for hoping;

Unfolded is the blossom of thy body;

But yet in vain I tarry that the flower

Of tender love shall break from out the bud

And joyous ripen into golden fruit.

60

Oh that ne'er pleases me and indicates

Some grave perversion in the ways of nature!

That heart doth please me not, that, stern and cold,

Constricts itself in years meant for emotion.

\section{RAIMOND}

Let's drop it, father Arc! Let her alone!

The love of my most excellent Johanna

Is, yea, a noble, tender fruit of Heaven.

And what is precious ripens still and slowly!

Now she still loves to dwell among the mountains

And from the care-free heath she fears indeed

To come down here beneath the lowly roof

Of mortals, where restraining sorrows dwell.

I often look from this deep dale at her

In still amazement, when, on lofty lea,

Amid her herd she stands alone, erect,

With noble stature, and her earnest gaze

Sends down upon the little lands of Earth.

She then to me portends a higher something,

And oft methinks she stems from other ages.

THIBAUT

It is just that that is not to my liking!

She flees the joyous company of her sisters, Seeks out the desert mountains, and deserts Her nightly couch before the cock's clear call; And in the dread-filled hour, when mere man

So gladly joins with trusted fellow-men,

She steals, e'en like the bird of hermit-habits,

Off to the grayish, sombre spirit-realm

Of night, advances to the cross-roads, and

Holds secret converse with the mountain air.

Wherefore does she always select this spot

And drive her herd on straightway hitherward?

I see her brooding there entire hours 
As underneath the Druid tree she sits, Which happy creatures all are wont to flee.

For there it is uncanny. An evil being

Has had its dwelling place beneath that tree

Already since the gray, old, Heathen times.

The ancients in the village tell each other

About this tree most shocking, spooky tidings;

Mysterious sounds of most peculiar voices

One oft discerns from out its gloomy branches.

E'en I, myself, when once in deepening twilight

My way was leading me past this same tree,

Have seen a ghostlike woman sitting there.

She slowly stretched, out from the wide-spread folds

Of her attire, a withered hand to me,

As if she meant to beckon, but I sped

On by, commending unto God my soul.

\section{RAIMOND}

(Pointing to the image of the saint in the shrine.)

The blessed nearness of this grace-rich image,

Which here diffuses Heaven's peace around it,

Not Satan's works, attracts your daughter here.

\section{THIBAUT}

Oh no! No, not in vain it shows itself

To me in dreams and anxious apparitions.

It's now three times, I have beheld her sitting

At Rheims upon the throne of our royal monarchs,

A sparkling diadem of seven stars

Upon her head, the sceptre in her hand,

From which sprang forth three lilies, totally white;

And I, her father, and both her sisters too,

And all the princes, counts and archbishops,

The very king himself bowed down before her.

How comes such radiance to my humble shelter?

$\mathrm{Oh}$, that betokens a most grievous fall!

Symbolically this warning-dream presents

To me the idle strivings of her heart.

She is ashamed of her own lowliness,

Since God adorned her body with rich beauty

And blessed her too with high and wonderous talents

Above all shepherd-maidens of this vale,

She nurses sinful pride within her heart, 
And pride it is through which the angels fell, Through which the spirit of hell takes hold of man.

\section{RAIMOND}

Who fosters a more virtuous, humble mind Than this your pious daughter? Is't not she Who serves her older sisters joyfully?

She is most highly gifted of them all,

But yet you see her as a lowly maid

Perform the hardest tasks in still obedience,

And through her hand in a most wonderous way

Your herds and likewise too your crops are thriving.

Around whatever deed she does pours forth

Good fortune passing bound and comprehension.

\section{THIBAUT}

Indeed, incomprehensible good luck!-

Peculiar fear comes o'er me at this blessing!

No more of this! I cease. I hold my peace.

Shall I accuse my own beloved child?

I can do naught but warn her, pray for her!

Yet I must warn: O flee this dreadful tree,

Remain not there alone and dig no roots

At midnight, and prepare there no potations,

And write not any symbols in the sand-

The spirits' realm is easy to tear cpen.

They lie there waiting under a thin cover,

And, hearing quietly, they storm aloft.

Stay not alone, for in the desert came

155

The Satan's-angel to the Lord of Heaven.

\section{THIRD SCENE}

Bertrand enters, a helmet in his hand.

Thibaut. Raimond. Johanna.

\section{RAIMOND}

Still! There comes Bertrand back from out the town.

See what he bears!

BERTRAND

You stare at me; you are

Bewildered at this strange, rare implement

Here in my hand!

\section{THIBAUT}

We are indeed. Speak up, 
How came you by the helmet? Why bring us

That evil token to this peaceful region?

(Johanna, who in both preceding scenes had stood aside in silence and distinterested, becomes attentive and comes nearer.)

\section{BERTRAND}

Scarce I myself can say just how the thing

Has got into my hand. I had bought up,

At Vaucouleurs, some iron implements.

A mighty throng I found there at the market,

For fleeing folk had even just arrived

From Orleans with evil war reports.

In uproar hastened all the town together,

And as I forced my way through the confusion,

There comes a brown Bohemian wench to me,

She has this helmet, lays sharp eye on me,

And speaks: "My lad, you're seeking for a helmet,

I know you're seeking one. So here, take this!

For but a petty price 'tis yours for keeps."

"Go to the mercenaries," I tell her,

"I am husbandman and need no helmet."

But she did not let up and argued further:

"No man may rightly say if he need not

A helm. A steel-like roof above one's head

Is now worth more than is a house of stone."

And so she chased me through the lanes, and urged

On me the helmet which I did not want.

I saw the helmet was so bright and fair,

And worthy of the head of any knight,

And as, in doubt, I weighed it in my hand,

Reflecting on how strange was this adventure,

The wench was quickly gone from out my sight;

The stream of folk had snatched her off with them.

And in my hands the helmet still remained.

JOHANNA (quickly and eagerly grasping at it).

Give me the helmet!

\section{BERTRAND}

What avails it you?

It is no finery for a virgin's head.

JoHANNA (snatches the helmet from him).

The helmet's mine, and it belongs to me. 


\section{THIBAUT}

What's coming o'er the girl?

\section{RAIMOND}

Grant her her wish!

This warlike ornament befits her well,

For in her breast is locked a manly heart.

Recall how she subdued the tiger-wolf, That grim, wild beast that so laid waste our herds, And was at once the dread of all our herdsmen.

She quite alone, the lion-hearted virgin,

Fought with the wolf and wrenched the lamb from him, That he was carrying off in bloody jowl.

Whatever valiant head this helmet covered

It cannot grace one that's more worthy!

ThIBAut (to Bertrand).

\section{Speak!}

What new misfortune of war has come to pass?

205

What tidings brought those fugitives?

\section{BERTRAND}

The king, and on this land of ours have pity!

God help

We have been smitten in two mighty battles,

The foe stands in the midst of France, forsaken

Are all our lands up to the river Loire.

And now his total might he has assembled

And with it he beleaguers Orleans.

May God protect the King!

\section{THIBAUT}

BERTRAND

Artillery is brought up from every side,

Immeasurable

And, as the dark'ning squadrons of the bees

Swarm 'round the hive throughout the summer-day,

As from the blackened air grasshopper hordes

Fall down and cloak the fields for miles and miles

With teeming masses seemingly unending,

So has a warlike cloud of divers nations

Poured forth upon the fields of Orleans,

And from the unintelligible mix

Of tongues, the camp in dull confusion roars.

For mighty Burgundy, the ruler, rich 
In lands, has brought up all his martial men,

Those from Liege and those from Luxembourg,

Those from Hainaut and from the land Namur,

And those who dwell in fortunate Brabant,

The sumptuous Ghentians, who in silk and satin

Strut proudly on, and those from Zeeland, whose

230

Clean cities rise from out the sea, and the

Herd-milking Hollanders, and those from Utrecht,

Yea, from the outermost West Friesland, those

Who look toward the ice-pole-they all follow

The power-wielding Burgundy's dread call

235

To war and wish to conquer Orleans.

\section{THIBAUT}

Oh the unholy, lamentable feud

That turns the arms of France against herself!

\section{BERTRAND}

Her too, the aged queen, proud Isabeau,

A princess of Bavaria, one sees

Full clad in steel go riding through the camp,

To rouse, with poison-pointed words, to rage

All nations here arrayed against her son,

Whom she once bore in her maternal womb!

THIBAUT

A curse upon her! And may God some day

Destroy her as he did proud Jezebel!

\section{BERTRAND}

The dreadful Salisbury, the wall-destroyer, Is leader of the forces of the siege.

With him the lion's brother, Lionel, And Talbot, who with murder-dealing sword,

Mows down entire nations in the battles.

In brazen insolence they now have sworn

To dedicate all maidens to disgrace,

And to the sword all those who bear the sword.

Four lofty barbicans they have built up

To overtop the town. Up there spies out

Earl Sal'sbury with a muraer-greedy eye, And counts the hastening wanderers in the lanes. Full many thousand balls of hundred-weight Are slung into the town. The churches lie

There now in rubble and the royal tower 
Of Notre Dame bows its exalted head.

They've dug, and filled with powder, passages.

And thus above this hellish realm now stands

The frightened city waiting every hour

That it with thunderclap the flames devour.

(Johanna listens with tense attention and sets the helmet on her head.)

\section{Thibaut}

But where were then our own heroic thanes, Saintrailles, Le Hire and France's mighty bulwark, The hero-hearted Bastard, that the foe, All powerful, so rushing forward thronged?

Where is the king himself? Does he look idly on

The realm's dire need and downfall of its cities?

\section{BERTRAND}

At Chinon now the king is holding court,

Since man-power fails, he cannot hold the field.

What use the leader's pluck, the hero's arm,

275

When pallid fear makes lame the arméd host?

A terror as if sent down here from God

Has also gripped the bosoms of the bravest.

In vain the summons of the prirces peal.

Just as the sheep in panic crowd together,

Whene'er the howling of the wolf is heard,

So seeks the Frank, forgetting his old fame,

Naught but the safety of his citadels.

One single knight alone, so I've heard say,

Has brought a feeble troop of men together

And goes to join the king with sixteen ensigns.

This knight is called?

$$
\text { JOHANNA (quickly). }
$$

\section{BERTRAND}

He's Baudricour. But scarce

Can he elude the foe's intelligence,

Who follows with two armies on his heels.

$$
\text { JOHANNA }
$$

Where does the knight abide? Tell, if you know!

\section{BERTRAND}

He stands but scarce removed a single day From Vaucoleurs. 


\section{Thibaut (to Johanna).}

What's that to thee? Thou ask'st

Of things that are not seemly for thee, maiden.

\section{BERTRAND}

Since now the foe's so mighty, and no help

Is longer hoped for from the king, they have

At Vaucoleurs adopted with one voice

A resolution yielding them to Burgundy.

Thus we shall wear no foreign yoke and cling

To our old, royal family line-perchance

Return to our own crown itself again,

When once Burgundy's reconciled with France.

JoHANNA (with enthusiasm).

Naught of agreements! Naught of giving up!

The saviour nears, he girds himself for battle.

At Orleans shall the foe's good fortune shatter,

His measure's full and he is ripe for reaping.

The virgin with her sickle soon will come

And mow the products of his pride to earth;

Down from the heavens she will tear his fame,

Which he has hung so high upon the stars.

Despair not! Flee not! Ere the fields of rye

Turn golden, ere the moon's bright disc is full,

Not any English steed shall longer drink

The wavelets of our beauteous flowing Loire.

BERTRAND

Oh, miracles don't happen any more!

JOHANNA

Miracles still happen! A snow-white dove

Will fly with eagle's boldness and attack

These vultures which now rend our fatherland.

It will beat down this proud Burgundian,

Betrayer of the realm, and then this Talbot,

The Heaven-storming, hundred-handed man,

And Sal'sbury, defiler of our temples,

And all these haughty island-dwellers, all,

Just like a herd of lambs she'll drive before her.

The Lord will be with her, the God of battles,

His trembling creature He will then select,

To magnify Himself, for He's Almighty. 


\section{THIBAUT}

What spirit now comes o'er the wench?

RAIMOND

The helm, that martially inspires her soul.

Behold your daughter now! Her eyes flash flames,

And glowing fire sparkles on her cheeks.

\section{JOHANNA}

This kingdom fall? This country full of fame,

The fairest that the sun eternal sees

Through all its course; this paradise of lands,

That God loves as the apple of His eye;

335

It bear the fetters of a foreign folk?

Here the heathen's might was crushed and here

Was raised the earliest Cross, the sign of Grace,

Here rest the ashes of the sainted Louis,

From here was launched the conquest of Jerusalem.

BERTRAND (astonished)

List to her speech! Whence has she drawn

This lofty Revelation! Father Arc!

To you God gave a daughter full of wonders!

\section{JOHANNA}

We shall not have our own kings any longer,

No master more born in our native land?

345

The king who never dies shall vanish from

This world-he who protects the holy plough,

Who the flock protects and fruitful makes the earth,

Who the chattel slave to freedom leads,

Who the cities happily groups around his Throne,

Who the weak assists and terrifies the wicked,

Who of envy knoweth naught, for he's the greatest,

Who a mortal is, and also mercy's angel

Upon this hostile earth here. For the throne

Of monarchs that with gold doth glimmer, is

340

The shelter of the destitute-Here stand

Both might and tenderness of heart. Here quakes

The guilty, while the righteous man comes near with trust

And jests e'en with the lions 'round the throne.

The foreign king, who comes here from abroad,

Whose fathers' sacred ashes nowhere rest

In this ancestral land, can he e'er love it? 
Who never was a youth among our youths, Unto whose heart our words are not appealing, Can he for us conceive a father's feeling?

\section{THIBAUT}

God fend for France and for our king, for we Are peaceful, rustic folk, who know not how To wield the sword nor wheel the martial steed.

Let us await in still obedience

Whomever victory gives us as a king.

The lot of battle is but God's decree, And our lord is he, who first receives The holy chrism and is crowned at Rheims. Come to our labor! Come! And each one think But on his nearest task. And let the great, 375

The princes of the earth, cast lots for Earth. The devastation we can calmly witness, The soil we till stands stormfast in its fitness. By flames our towns may to the earth be burned. The chargers' hoofs may trample down our grain,

But the new Spring will bring new crops again, And soon our fragile shelters are returned. (All except the Maiden depart.)

\section{FOURTH SCENE}

\section{JOHANNA (alone.)}

Farewell, ye mountains, ye beloved meadows, Ye old familiar, quiet vales, farewell! Johanna will no longer wander o'er you, 385 Johanna says to you farewell forever. Ye meadows, which I watered, and ye trees, Which I did plant, grow greener still in joy! Farewell, ye grottoes and ye cooling fountains! Thou, Echo, the dear voice of this loved valley, Who oft gave answer to my own refrain, Johanna goes and never comes again!

Ye places, all, of my still, silent pleasures, You now I leave behind for evermore.

Disperse yourselves, ye lambs, upon the pastures,

A flock no longer pastored as of yore, For there's another herd which I must treasure 
On danger's fields, that will be wet with gore.

Thus has the spirit's call to me been given;

Nor by vain, earthly longing am I driven.

For Who on Horeb's heights one day descended

To Moses in a fiery bush of flame

And him to go 'fore Pharoah's throne commended;

Who once the pious son of Jesse's fame,

The shepherd boy for His own knight intended,

Who e'er his grace to shepherds did proclaim, He spoke to me from this tree's leafy sweetness:

"Go forth! Thou shalt for me on earth bear witness.

With cruel ore thou shalt thy limbs belumber,

With steel thou shalt bedeck thy tender breast,

Nor in thine heart dare love of men e'er slumber

With sinful flames of idle, earthly lust.

Ne'er shall a bridal wreath thy locks encumber,

Nor darling child shall blossom at thy breast.

But thee I shall with martial honors high

415

Above all women on earth, thee, magnify.

For when in strife the most courageous tarry,

When France's final fate doth nearer steal,

Then thou my oriflamme shalt forwards carry

And, as the nimble reaper clears the field,

The haughty victor thou shalt reap and harry. And backward thou shalt turn his fortune's wheel, And bring to Gaul's heroic sons salvation, Free Rheims, and crown the king of thine own nation!"

A token Heaven to me has foreordained.

It sends this helm to me; it comes from Him.

Its iron gives me strength, divine, unfeigned.

My courage flames like that of Cherubim;

It urges me to battle unrestrained,

It drives me forth as with a stormwind's vim.

The battle-cry I hear. With might it's ringing.

The war horse rears, the trumpets are all singing.

(She goes out.) 


\section{FIRST ACT}

The Court of King Charles at Chinon.

FIRST SCENE

Dunois and Du Chatel.

\section{DUNOIS}

No, this no longer I'll endure. I say

I'm finished with this king, who shamefully

Deserts himself. Within my bosom bleeds

435

My valiant heart, and burning tears I fain would weep,

That robbers with the sword are now dividing

The royal domains of France; that noble cities,

Which with this monarchy have grown old,

Hand over to the foes their rusty keys,

While here in calm and inactivity

We waste good time so precious for salvation.

I hear that Orleans is threatened, and

I rush down here from far-off Normandy.

The king, I think, in armament arrayed,

I'll find already in his army's van

And find him-here! surrounded by his band of jesters

And troubadours, unravelling captious riddles,

And giving gala fêtes for Mistress Sorel,

As if serenest peace ruled in his realm!

His Field Marshal has left. He can no longer

Behold the horror.-I'll desert him too

And give him over to his evil fate.

Here comes the king!

\section{Du Chatel}

\section{SECOND SCENE}

King Charles and the preceding characters.

CHARLES

The Field Marshal sends back his sword to me,

Refuses me his service. In Heaven's name!

So we are rid of one ill-humored man,

Who wished to master us beyond endurance.

DUNOIS

A man is worth a lot in such dire times.

I should not like to lose him willy-nilly. 


\section{Charles}

Thou speakest but through joy in contradicting. While he was here you never were his friend.

\section{DuNors}

He was a proud, vexatious, stubborn fool, Who knew not when to stop-this time, however, He knows it, knows the time to leave, 465

When honor is no longer to be had.

\section{CHARLES}

Thou art now in thy most engaging humor.

I'll not disturb thee in it.-Du Chatel!

Ambassadors are here from the old king,

René, the master praised for melodies

And famed afar. We must regale them well.

And give to each of them a golden chain.

(To the Bastard.)

And wherefore laughest thou?

\section{DunoIs}

That golden chains

Thou shakest from thy mouth.

\section{Du Chatel}

My lord, there is

No money handy in thy treasury.

Charles

Then get some! Noble singers never may

Depart unhonored from this court to roam.

They make our dry and withered sceptre bloom,

They weave the never-dying verdant spray

Of life into the else unfruitful crown,

They place themselves as lords in lords' array;

Of blithesome wishes they construct their throne, And not in space their carefree realm holds sway.

Hence shall the singer with the king abide,

They both on mankind's summits shall reside.

Du Chatel

My royal master! I have spared thine ear As long as there was counsel still and aid, But dire necessity now frees my tongue.

Thou hast naught more to give; alas, thou hast

No more wherefrom thou mayst tomorrow live!

The flood-tide of thy riches has run out, 
And lowest ebb is now within thy vaults.

Thy troops till now have not been paid their hire.

They murmur threatening to withdraw. I scarce

Know how thine own royal domicile can be

Maintained in meager, not in princely, manner.

\section{CHARLES}

Give as a pledge my royal tolls and customs, And let the coin be loaned thee by the Lombards.

\section{DU CHATEL}

My lord, thy royal revenue and customs

Are pledged three years already in advance.

\section{DuNoIs}

And meanwhile pawn and land will both be lost.

\section{CHARLES}

To us remain still many fair, rich lands.

\section{DUNOIS}

As long as it please God and Talbot's sword!

When Orleans is taken, then mayest thou

Along with old king René, pastor sheep.

\section{CHARLES}

Thou ever tryest thy wit against this king, And yet it is this very landless prince Who just today endows me royally.

\section{DUNOIS}

Not with his crown of Naples, let us hope!

For Heaven's sake no! For it is vendible,

So have I heard, since he's been tending sheep.

\section{Charles}

That is a jest, a merry game, a fête,

Which he allows himself and his own heart, To found themselves a blameless, pure world 'Mid this barbaric, crude reality.

But what he wishes, that is great and royal,He wants to bring again the olden times, When gentle, courtly love prevailed, when love The knightly hearts of heroes elevated, And noble ladies sat in seats of judgment, With gentle manner settling all fine points. In those times dwells the cheerful, hoary king, 
And, as they live still in the olden ballads, Thus will he set them up here on our earth, Just like a heavenly city in golden clouds.

He hath established too a court-of-love,

To which the noble knights shall fare as pilgrims,

Wherein chaste ladies shall majestic reign, Where pure, courtly love shall now return, And me he has elected Prince of Love.

\section{DUNOIS}

From my own source I'm not so sore perverted That I should scorn the majesty of love.

I take my name from her. I am her son; And all my heritage lies in her realm. My father was the Prince of Orleans.

To him no woman's heart, but could be stormed, Yet was no hostile fort for him too strong. Wilt thou be called the Prince of Love in truth, Then be the bravest of the brave. As I Have read in well-known, olden books, then love

Was ever paired with high and knightly deeds, And heroes, I was taught, not shepherd swains, Did seat themselves at Arthur's table 'round. Who cannot bravely be the shield of beauty, Deserves not beauty's golden prize. Here is

The battle-ground! Fight for thy fathers' crown!

Defend now with thine own chivalric sword Thy property and noble women's honor! And when thou hast, from streams of foeman's blood, Made conquest bold of thy inherent crown, Then is it time, that fits thee as a prince, To crown thee with the myrtle wreath of love.

What's news?

CHARLES (to a Squire who enters)

SQUIRE

Councilmen from Orleans beg a hearing.

Conduct them in!

\section{Charles}

(Squire departs)

It's help they will demand.

What can I do, myself in need of help! 


\section{THIRD SCENE}

Three Councilmen join the others.

\section{CHARLES}

Be welcome, my most loyal citizens

Of Orleans! How fares my goodly town?

Does it continue with accustomed courage

To stand against the foe beleaguering it?

\section{COUNCILMAN}

Oh, Sire! the utmost threat impends, and hourly waxing,

Destruction surges on toward the town.

The outer breastworks are destroyed, the foe

Wins over new terrain in each attack.

The walls are now denuded of defenders,

For fighting restlessly our troops make sallies,

But few behold again their home-town's gates.

A plague of hunger too imperils the town.

Hence has the noble Count of Rochpierre, Who holds command in this our direst need,

Contracted with the foe, in wonted custom,

To yield himself on the twelfth day from now,

If in this time no force upon the field

Appear that's strong enough to save the city.

(Dunois makes a violent gesture of anger.)

\section{CHARLeS}

The respite's short.

\section{COUNCILMAN}

And therefore we are here

With hostile escort, that we may implore

Thy princely heart to pity thy poor town

And send us help within this stated time;

Else he surrenders it on the twelfth day.

\section{DuNOIS}

And could Saintrailles really lend his voice

To such a shameful contract?

\section{COUNCILMAN}

$$
\text { No, my lord! }
$$

So long as that brave man still lived there ne'er

Could be nor talk of peace nor of surrender.

So he is dead!

\section{DUNOIS}




\section{COUNCILMAN}

Yea, on our wall he sank,

The noble hero fighting for his king.

\section{CharLes}

Saintrailles dead! Oh in that single man

585

Sinks my whole host!

(A Knight enters and speaks a few words softly with the Bastard, who starts in surprise.)

\section{DuNOIS}

That too!

\section{CharLes}

Well, what is up?

\section{DUNOIS}

Count Douglas sends us news. The Scottish troops

Rise up and threaten to withdraw, unless

This very day they get the wages due them.

Du Chatel!

\section{Charles}

Du Chatel (shrugs his shoulders)

Sire, I know no counsel.

\section{Charles}

Yea, promise, all thou hast, e'en half my realm-

Pledge,

Du Chatel

Naught helps! Too often they've been proffered pledges!

\section{Charles}

They are the finest troops in all my host!

They shall not now, not now, abandon me!

CoUnCILMAN (falling at the king's feet)

Oh king, assist us! Of our needs be mindful!

\section{ChARLES (despairingly)}

Can I by stamping on the ground raise armies?

Will fields of grain grow in my outstretched hand?

Tear me to pieces, tear my heart from me,

Mint it instead of gold! My blood I have

For you, but silver have I not, nor soldiers!

(He sees Sorel entering and hastens to her with outstretched arms.) 


\section{FOURTH SCENE}

Agnes Sorel, a casket in her hand, joins the group.

\section{CHARLES}

Oh, my dear Agnes! My beloved life!

Thou com'st to snatch me from my desperation!

I have thee now; I flee unto thy bosom.

Naught is yet forfeit, for thou still art mine.

My dear, good king!

SOREL

(looking around with anxiously inquiring glance.)

Du Chatel?

Oh Dunois! Is it true?

Sadly!

\section{Du Chatel}

SOREL

Is the need so great?

There's lack of pay? The troops wish to withdraw?

Yes, sadly this is true!

Du Chatel

SOREL (forcing the casket on him.)

Here, here is gold.

Here are my jewels! Melt my silver down!

For purchase or for pawn put up my castles-

Put lien upon my holdings in Provence, Turn all to cash and satisfy the troops! Away! And lose no time!

(Urges him to depart)

\section{CHARLES}

How now, Dunois? Now, Du Chatel? Am I

Still poor, when I the crown of womanhood

Possess? As noble as myself is she

By birth. The royal blood of Valois is itself

Not purer. Daintily would she adorn

The foremost throne on earth--but that she spurns.

She will be but my love alone and bear that title.

Has she allowed me e'er to make a gift

Of higher value than an early flower

In winter or a seldom fruit? From me

She takes no sacrifice and brings me all! 
Risks her entire riches and possessions

With noble soul on my submerging fortune.

Yes, she's another maniac as thou, And throws her all into a burning house And pours into Danaides' leaky vessel. Thee she shall never rescue, but herself She'll bring with thee to ruin.

SOREL

Believe him not!

He has ten times his life for thee imperiled, And now is wroth that I imperil gold.

What? Haven't I for thee with joy surrendered All that is more esteemed than gold and pearls,

And should I now retain for me my fortune?

Come! Let us cast all superficial sham Of life away from us! Let me give thee A noble instance of renunciation! Transform thy noble raiment into soldiers, Thy gold to iron; and all, whate'er thou hast, Cast it away, resolved to save thy crown!

Come! Come! We'll share alike both want and danger!

Let us bestride the war-accoutered charger, Expose our tender bodies to the shafts

of glowing sun and take the clouds above

To be our coverlet; the stone, our pillow.

The hardened warrior will bear his woe In patience when he sees his king just like The poorest churl endure and persevere!

ChARLES (smiling)

Yea, now an olden word, in saying sooth, Fulfills itself in me, which once a nun In Clermont spoke in a prophetic spirit. A woman, so the nun declared, would make Me victor over all my enemies 655 And would reconquer me my father's crown. Far off I sought her in the hostile camp, I hoped to reconcile my mother's heart. Here stands the heroine who leads to Rheims. Through love my Agnes renders I shall conquer! 
SOREL

Thou shall effect it through thy friends' bold sword.

CHARLES

Much too I hope from discord 'twixt my foes.

For sure intelligence to me has come

That 'twixt the haughty lords of England and

My cousin Burgundy not all now stands

665

As formerly. Hence I have sent La Hire, With messages dispatched unto the Duke Attempting to succeed in drawing back

That angered peer to his old pledge and duty.-

With every hour I await his coming.

Du CHATEL (at the window)

A knight comes now agallop in the court.

\section{CHARLES}

Oh welcome messenger! Now we shall know Quite soon if we shall yield or we shall conquer!

\section{FIFTH SCENE}

La Hire and the preceding

\section{Charles (going to meet him)}

La Hire! Bring'st thou hope or bring'st thou none?

Explain in brief! What have I to expect?

LA HIRE

Expect naught more save from thy trusty sword.

\section{CHARLES}

The haughty Duke will not be reconciled?

Oh speak! How did he entertain my message?

\section{LA HIRE}

Before all else, yea, e'en before he can

Unto thee lend an ear, he first demands

That thou to him deliver Du Chatel,

Whom he doth name the murderer of his father.

CHARLES

And what if we deny his shameful terms?

LA HIRE

Then be the bond asunder ere it starts.

CHARLES

Hast thou forthwith, as I commanded thee, 
Then challenged him to fight me on the bridge In Montereau just where his father fell?

\section{LA HIRE}

I threw thy gauntlet down 'fore him and said

Thou would'st forgo thy rights of majesty,

And as a knight do battle for thy realm.

690

But he replied: To him there ne'er was need

To fight for that which he already held.

But if thou wert so longing for a fight

Then thou wouldst find him soon at Orleans,

Whereto it is his will to go tomorrow.

695

Therewith he laughing turned his back on me.

\section{CHARLES}

Did not within my Parliament arise

The pure voice of justice undefiled?

$$
\text { LA HIRE }
$$

It has grown mum amid the wrath of parties.

The verdict of the Parliament declared

Thee and thy line divested of the throne.

\section{DunoIs}

Hah! Brazen pride of commoners turned lords!

\section{Charles}

Hast thou tried nothing as concerns my mother?

\section{LA HIRE}

Concerns thy mother?

\section{Charles}

Yes, and how did she behave?

\section{LA HIRE}

(After meditating a few moments)

'Twas just the feast day of the king's coronation

When I arrived at Saint Denis. Adorned

As for a triumph were the Parisians all,

In every byway arcs of honor rose.

Through which the Engellander's king made entry.

Bestrewn with blossoms was the way, and cheering,

As if our France had won its fairest conquest, The rabble clamored 'round his coach of state.

SOREL

They cheered-exulted that upon the heart

Of their most loving, gentle king they trampled! 


\section{LA HIRE}

I saw the youthful Harry Lancaster,

The boy, upon the royal seat of our

Saint Louis sitting and his haughty uncles, Bedford and Gloucester, standing next to him, And our Duke Philip knelt before the throne And gave the oath of fealty for his lands.

\section{CHARLES}

Oh peer, forgetting honor! Unworthy cousin!

\section{LA HIRE}

The child was terror-struck and stumbled, when

The high steps of the throne he did ascend.

"An evil omen!" murmured all the folk, And there arose a long resounding laughter.

Then stepped the ancient queen, thy mother, up

To him, and-but it angers me to say it!

Well?

\section{CHARLES}

\section{LA HIRE}

In her arms she clasped the little boy And set him on thy father's throne herself.

Oh, mother! mother!

\section{CHARLES}

\section{LA HIRE}

Burgundians, the murder-wonted bands, E'en the frenzy-mad

Glowed hot with shame to look upon this scene. And she, aware of it, turned to the crowd, And cried in a loud voice: "Thank me, ye Frenchmen, That I graft on this sickly tree so sound

A scion, and defend you from this misBegotten son of a delirious father!"

(The King covers his face; Agnes hastens to him and clasps him in her arms; all those standing around express their aversion and horror.)

DuNoIs

The vixen! The terror-breathing, old Megaera!

CHARLES

(after a pause, to the Councilmen)

Ye now have heard how matters stand with me. 
Delay no longer! Go to Orleans

Again and notify my loyal town

That I release it from its oath to me.

It may give heed to its salvation now

And yield itself to the Burgundian's mercy.

He's called the Good, and he will be humane.

745

Dunors

What, Sire? Wilt thou forsake thy Orleans?

Councilman (kneels down)

My royal lord! Do not withdraw thy hand

From us! Do not give up thy loyal town

Unto the cruel mastery of England?

It is a noble jewel in thy crown,

And none hath to our kings, thine ancestors,

Preserved its troth more sacredly.

DuNoIS

Defeated? Is it meet to yield the field

Are we

Ere e'en one sword's been thrust to hold the city?

With one mere word, before one drop of blood

755

Has flowed, dost thou intend to give away

The fairest city from the heart of France?

\section{Charles}

Enough of blood has flowed, and that in vain!

The heavy hand of Heaven is against me.

Defeated is my host in every battle,

My parliament rejects me, my chief city,

My people hail my foe with jubilation,

Those who are nearest me by blood forsake,

Betray me; my own mother nourishes

The foreign, hostile brood at her own breasts.

We will withdraw yonside the river Loire, And yield unto the pow'rful hand of Heaven, Which now is with the Englander.

\section{SOREL}

May God forbid, that we, of our own selves

Despairing, turn our back upon this realm!

That word came not from thine intrepid breast.

His mother's most unnatural, brutal deed

Hath broke my sovereign's own heroic heart! 
Thou w'lt find thyself again composed and manly And stand against that fate with noble courage

Which grimly fights against thee now.

CHARLES (lost in gloomy meditation)

Is it not true?

A darkly freighted, fearful fate prevails

Through Valois's dynasty; it is forsaken

By God. My mother's heinous deeds have led

The furies' wrath into this very house.

780

My father lay full twenty years in madness.

Three elder brothers hath grim death 'fore me

Mowed down. It is the Heaven's verdict that

The house of Charles the Sixth shall be submerged.

SOREL

In thee it will arise renewed in youth!

Have faith in thine own self! Oh, not in vain

Hath gracious destiny preserved but thee,

Of all thy brothers, thee alone, the youngest,

Hath called unto this undesired throne.

Within thy gentle soul the Heaven hath

Prepared itself a leech for all the wounds

Which parties' wrath inflicted on this land.

The flames of civil war thou wilt extinguish.

My heart doth tell me thou shalt plant the peace,

And of the Frankish realm be the new founder.

795

CHARLES

Not I. The rough and storm-bewildered time

Demands a helmsman more endowed with strength.

I could have made a peaceful people happy,

But one that's wild wrought up I cannot tame,

Nor open with the sword for me their hearts,

Which turned away are shut up tight with hate.

SOREL

The folk is blind, delusion numbs its senses,

But yet the ecstasy will pass away;

There will awake, the day no more is distant,

The love for its hereditary king,

Which is deep planted in the Frankish breast;

The olden hate, the jealousy, will waken,

Which separates both folks as foes eternal.

His very luck will fell the haughty victor. 
And so do not desert in too great haste

The battle field; contest each foot of earth,

Defend, as if it were thy very breast,

This Orleans! Cause rather to be sunk

All ferry boats, all bridges to burn down,

Which over this divider of thy realm,

815

The Stygian waters of the Loire, would lead thee.

\section{ChARLES}

What I was able, I have done. I have

Made offer of myself for knightly combat

For my own crown-And they deny me that.

My people's lives to no avail I squander,

And all my cities sink into the dust.

Shall I, like that unnatural mother,

Let my own child be quartered with the sword?

No, I'll renounce my right, that it may live.

\section{DuNoIs}

How, Sire? Is that the language of a monarch?

825

Does one thus give a crown away? The worst

Of all thy people stakes his land and life

To back his point of view, his love, his hate.

The party's first, whene'er the bloody sign

of interparty conflict is unfurled.

830

The husbandman deserts the plow; his wife,

Her distaff; children, gray-beards arm themselves;

The townsman burns his town, the countryman

With his own hands ignites his growing crops,

To injure thee or to promote thy weal,

And to assert the will within his heart.

He spareth naught, and he doth not expect

Forbearance, when his honor calls, when he

Doth battle for his Gods or for his idols.

Hence out with this insipid sympathy;

That is not seemly to a kingly breast!

Let thou the war rage on as it began!

Thou hast not lightly kindled it thyself.

The folk must sacrifice itself unto its king.

That is the fate and law of all the world.

The Frank nor knows, nor wills it otherwise.

Worth nothing is the nation, which will not

With joy stake everything upon its honor. 


\section{Charles (to the Councilmen)}

Await from me no other resolution. God shelter you! I can no more.

\section{DUNOIS}

The victory-god forever turn his back

On thee as thou dost on thy native realm!

Thou hast forsak'n thyself, so I forsake thee.

Not England's and Burgundy's joined might,

Thine own faint spirit casts thee from thy throne.

The kings of France are heroes when they're born,

But thou art not thus martially engendered.

(To the Councilmen)

The king surrenders you. But I myself,

To Orleans, my fathers' town, will speed

And underneath its rubble dig my grave.

(He is about to depart. Agnes Sorel detains him.)

SOREL (to the King)

Oh, let him not depart from thee in anger!

His mouth speaks cruel words, and yet his heart

Is true as gold. He is indeed the very one

Who loves thee warmly, oft for thee hath bled.

Now come, Dunois! Confess! It was the fervor

of noble wrath that went too far!-And thou,

Forgive thy loyal friend his hasty speech!

Oh come, come! Let me quickly reunite

Your hearts, ere rapid wrath, unquenchable,

The dread and ruinous, unleash its flames!

(Dunois looks fixedly at the King and seems to be waiting for an answer.)

\section{Charles (to $D u$ Chatel)}

We'll go across the river Loire. Now let

My goods be brought on board!

\section{Dunors (quickly to Sorel)}

And so farewell!

(He turns quickly and departs, the Councilmen follow.)

SOREL (wrings her hands in desperation)

$\mathrm{Oh}$, if he goes, then are we quite forsaken!

La Hire, follow him! Seek to assuage him!

(La Hire departs) 


\section{SIXTH SCENE}

Charles. Sorel. Du Chatel.

\section{ChaRLES}

Is then the crown a so unique possession?

Is it so sorely hard to part with it?

I know a thing still harder to endure.

To let one's self by these defiantly

O'er-weening natures be controlled, to live

By grace of haughtily imperious vassals,

That is the hardest for a noble heart

And bitterer than to succumb to fate.

(To Du Chatel who is still hesitating)

Do what I've ordered thee!

Du CHATEL (throws himself at his feet)

Alas, my king!

\section{Charles}

It is resolved! There'll be no further words!

\section{DU Chatel}

Make peace now with the Duke of Burgundy.

Else can I see for thee naught of salvation.

\section{Charles}

Thou counsel'st this and thine own blood it is

Wherewith I must both sign and seal this peace?

\section{Du Chatel}

Here is my head. Oft I have ventured it

For thee in battles, and I lay it now

890

For thee with pleasure on the bloody scaffold.

Placate the Duke. Deliver me to the

Entire sternness of his wrath, and let

My flowing blood appease his ancient hate!

\section{ChARLES}

(looks at him for some time in silence and in deep emotion.)

Well, is it true? Are things so bad with me

That my own friends, who see right through my heart, Point out the road of shame for my salvation?

Yes, now I recognize my grievous fall, Since all reliance in my honor's gone. 
Charles

Speak not a word! Arouse me not!

Had I to turn my back on ten domains, I will not save me with my friend's dear life. Do what I've ordered thee! Now go and have My armament embarked!

\section{DU ChATEL}

Be done.

It shall at once

(He arises and goes. Agnes Sorel weeps violently.)

\section{SEVENTH SCENE}

Charles and Agnes Sorel.

CHARLES (clasping her hand.)

$\mathrm{Oh}$, be not sorrowful, my Agnes.

Yonside the Loire there also lies a France.

We go into a much more happy land.

There laughs a milder ne'er beclouded heaven, And gentler breezes blow, and gentler customs Receive us there. And there the songs abide And fairer blossom there both life and love.

\section{SOREL}

Oh, must I look upon this day of misery!

The king must go away in banishment, The son must wander from his father's house And look upon his cradle o'er his shoulder. Oh, pleasant country, that we now are leaving Ne'er shall we more set foot on thee rejoicing.

\section{EIGHTH SCENE}

La Hire returns. Charles and Sorel.

\section{SOREL}

You come alone. You do not bring him back?

(While she observes him more closely.)

La Hire! What's wrong? What says your look to me?

What new misfortune has occurred! 


\section{LA HIRE}

\section{Bad luck}

Has been exhausted, sunshine comes again!

SOREL

What's that? Oh, please!

LA HIRE (to the King.)

Recall the delegates

From Orleans!

\section{Charles}

And why? What has occurred?

\section{LA HIRE}

Oh call them back again! Thy luck hath changed.

A battle has occurred. Thou hast prevailed.

\section{SOREL}

Prevailed! Oh heavenly music of that word!

\section{CharLes}

La Hire! Thou art by fabulous report beguiled. Prevailed! I have no longer faith in victory.

\section{LA HIRE}

$\mathrm{Oh}$, thou wilt soon believe in greater wonders.

There comes the archbishop. He leads the Bastard

Into thine arms again.

\section{SOREL}

Of triumph bearing heaven's noble fruits

Oh fairest flower

At once, peace and appeasement!

\section{NINTH SCENE}

Archbishop of Rheims. Dunois.

Du Chatel with Raoul, a Knight in armor, joins the preceding.

ARCHBISHOP (leads the Bastard to the

King and lays their hands in each other's.)

Lords, embrace!

Let all your grudge and discord vanish now,

Since Heaven itself proclaims that it's for us.

(Dunois embraces the King.)

\section{ChARLES}

Snatch me from out my doubt and my surprise! 
What does this solemn seriousness portend?

What has effected this quick change?

ARCHBISHOP

(leads the Knight forward and places him before the

King.)

Now speak!

RAOUL

We had brought up some sixteen companies,

Folk from Lorraine to join to thine host,

And Baudricour, the knight from Vaucouleurs,

Was our leader. When we now attain

The heights of Vermanton, and in the vale,

Through which the Yonne flows, descended,

There stood before us on the wide-stretched plain the foe, 945

And weapons glistened when we looked arrear:

We saw ourselves surrounded by two armies.

There was no hope to conquer or to flee.

Then sank the heart of even the most brave,

And all, despairing, wished to yield their arms.

950

Now while our leaders with each other still

Were seeking counsel, and were finding none,

Behold a seldom wonder met our eyes!

For out the forest's depths quite suddenly

Stepped forth a virgin, helmet on her head,

955

Like to a martial goddess, fair at once

And fearful to behold, around her neck

In darksome ringlets fell her hair; a gleam

From Heaven seemed to light the sky on high,

As she raised up her voice and thuswise spoke:

"Why timid? valiant Frenchmen! At the foe!

And were there more of them than ocean's sands,

God and the Holy Virgin lead you on!"

And quickly from the ensign-bearer's hand

She snatched the banner, and before the train

With valiant bearing strode the mighty maid.

We, dumb with wonder, follow, without willing,

The lofty banner and the standard-bearer,

And on the foe we straightway rush in storm,

Who, highly shocked, stands there immobilized,

With wide-eyed, stony stare, amazed to see

The miracle that 'fore his eyes unfolds. 
Yet quick, as if God's terror laid its grip

Upon them, now they turn and flee

And, casting ward and weapons from their persons,

975

The total army through the field disperses.

No word of power, no call of leader helps.

With terror senseless, without looking back,

Both horse and man plunge to the river's bed,

And let themselves be choked without resisting.

It was a slaughter, call it not an onslaught!

Two thousand enemies bedecked the fields,

Not counting those the river swallowed up.

And of our troops no single man was missing.

\section{CharLes}

Quite strange, by God! Most wonderous and strange!

SOREL

And 'twas a maid who worked this miracle?

Whence came she here? Who is she?

\section{RAOUL}

Will she unto the king alone reveal.

Who she is

She calls herself a seeress and a God-

Commissioned prophetess, and she makes promise

To rescue Orleans ere the moon shall change.

The folk believes her and now thirsts for fighting.

Thine host she follows; soon she will be here.

(One hears the pealing of bells and the clashing

of arms beaten against each other.)

You hear the clamor and the peal of bells?

It's she. The folk salutes God's emissary.

Conduct her in-

Charles (to Du Chatel)

(To the Archbishop)

What shall I think of this?

A maiden brings me victory; and just now, When but the arm of God can rescue me! This is not in the normal course of nature, And dare I now believe in miracles?

MANY VoICES (behind the scene)

Hail, hail the virgin, our deliveress! 
She comes!

\section{CharLes}

(To Dunois.)

You occupy my seat, Dunois!

We wish to prove this maid-of-miracles.

If she's inspired, and is sent from God,

Then she will know how to detect the king.

(Dunois seats himself; the King stands at his right, next to him Agnes Sorel; the Archbishop and the others VIS-A-VIS, so that the intervening space remains unoccupied.)

\section{TENTH SCENE}

The preceding. Johanna accompanied by the Councilmen and many Knights who completely fill the background of the scene. She advances with noble bearing and scrutinizes those standing around one after the other.

\section{DUNOIS}

(After a deep, solemn stillness)

Is't thou, oh wonder-working maiden-

\section{JOHANNA}

(interrupts him, looking at him with clearness and majesty.)

Bastard of Orleans! Wilt thou tempt thy God!

Arise from this, a seat that seems thee not!

To this more mighty man have I been sent.

(She goes with decisive step up to the King, genuflects before him and immediately stands erect again, retiring. All those present express their astonishment. Dunois leaves his seat and space is left vacant before the King.)

\section{Charles}

Thou dost for the first time today behold 1010

My countenance. Whence comes to thee this knowledge?

JOHANNA

I saw thee when none else but God beheld thee.

(She approaches the King and speaks mysteriously.)

In recently departed night, bethink thee,

When all about thee lay in deepest sleep

Interred, didst thou arise from thine own couch 
And make a fervent prayer unto thy God. Let these withdraw, and I'll relate to thee The content of thy prayer.

\section{Charles}

What I to Heaven

Confide, I need not hide from mortal men.

Disclose to me the content of my pleading.

Then I no more will doubt that God inspires thee.

\section{JOHANNA}

The prayers that thou didst pray were three in number.

Give heed if I do name them for thee, Dauphin!

At first thou didst make plea unto high Heaven,

If unjust goods were cleft unto thy crown,

1025

If any other grievous guilt, still yet

Left unatoned e'en from thy father's time, Had called this tear-filled conflict into being, Then it should claim thee as thy people's offering, And pour upon thine head, and thine alone,

The fullest measure of its wrath.

\section{ChARLES (retreats in awe)}

Who art thou, mighty being? Whence thy coming?

(All show their astonishment.)

\section{JOHANNA}

Thou then didst make to Heaven the second plea:

If its high will and resolution be

To wrest the sceptre from thy dynasty,

To take away from thee all that thy fathers,

The monarchs of this realm, had once possessed,

Then would'st thou pray it to preserve to thee

Three single properties: a peaceful breast,

Thy friend's true heart, and then thine Agnes' love.

(The King conceals his face, weeping violently; great commotion of astonishment among those present. After a pause.)

Shall I now name for thee thy third petition?

\section{CHARLES}

Enough! I credit thee! So much no man

Can do! The all-high God has sent thee hither.

ARCHBISHOP

Who art thou, holy, wonder-working maiden? 
What happy land did bear thee? Speak! Who are

The God-belovéd parents who begot thee?

\section{JOHANNA}

Most reverend Sir, Johanna is my name.

I'm but a shepherd's lowly daughter, born

In my own sovereign's village, Dom Remi, Which lies within the diocese of Toul. 1050

And I have herded there my father's sheep

From childhood on. And much and often I

Have heard them tell of this strange island-folk,

Who've come across the sea to make of us

Their slaves, and force on us a master born

On foreign soil, who does not love our people;

And that already your great city, Paris, They've occupied, and now control our realm.

Then plaintively God's mother I invoked

To turn from us the shame of foreign chains,

And to preserve for us our native king.

Close to the little town where I was born

There stands an ancient image of God's mother,

To which came many pious pilgrim-trains.

Near by a holy oak tree stands, long-famed

Through many miracles of sacred power.

And in this oak tree's shade I liked to sit,

While tending sheep, for so my heart impelled,

And if one lamb was lost in these wild mountains,

My dream would always point it out to me

When I was sleeping in this oak tree's shade.

And one time, as I sat a long night through

Beneath this tree in pious meditation, And to the powers of sleep set up resistance,

There came the Holy One to me, a sword

And banner bearing, otherwise, as I,

Clad as a shepherdess, and said to me:

"'Tis I! Get up, Johanna! Leave thy herd!

The Lord now calls thee to another business!

Take thou this banner! Gird thee with this sword!

And extirpate therewith thy people's foes,

And lead thy sovereign's son with thee to Rheims;

And crown him with the royal diadem!"

But then I spake: "How can I such a deed 
Dare undertake, I, but a tender maid

Untaught in the destructive ways of war?"

And she replied: A virgin sure can bring

To pass whate'er is glorious on earth,

If she doth but resist all earthly love.

Just look on me! A maiden chaste as thou,

1090

I to the Lord divine have given birth,

And I'm myself divine!" And then she touched

My eyelid, and, as I looked up on high,

There was the heaven full of youthful angels,

Who carried pure, white lilies in their hands,

1095

And a sweet tone pervaded all the ether.

And thus three nights succeeding one another

The Sainted One appeared and called: "Get up, Johanna!

The Lord now calls thee to another business."

And when she on the third night did appear,

She was enraged and scolding spoke these words:

"Obedience is woman's lot on earth,

And stern forbearance is her grievous duty.

She must be purified through strictly serving.

Who here hath served, is great in the hereafter."

And speaking thus she let the herd-girl's garb

Fall off and stood there as the Queen of Heaven,

Amid the glory of the sun supernal,

And golden cloud-banks bore her up on high,

Receding slow to lands of bliss eternal.

(All are moved. Agnes Sorel, weeping violently,

hides her countenance on the bosom of the King.)

ARCHBISHOP (after a long silence.)

In face of such divine accreditation

Must every doubt of earthly wit be silent.

The deed attests that she doth speak the truth;

But God alone can work such miracles.

DUNOIS

I credit not her wonders, but her eye,

The pure innocence upon her visage.

\section{CHARLES}

Am I, a sinner, worthy of such favor?

All-searching eye, that cannot be deceived,

Thou seest my inmost heart and knowest me humble! 


\title{
JOHANNA
}

Up there the meekness of the high shines brightly,

Thou hast bent down, so He exalts thee rightly.

\section{ChARLES}

Thus shall I to my foes resistance tender?

\author{
JOHANNA
}

Subjected France before thy feet I'm placing!

CHARLES

And Orleans, sayest thou, will not surrender?

JOHANNA

You'll sooner see the Loire its course retracing .

CHARLES

Shall I to Rheims as conquering hero fare?

\section{JOHANNA}

Through foes by thousands I shall lead thee there.

(All the Knights present raise a din with their lances and shields and give signs of courage.)

\section{DunoIs}

Just place the Maiden at the army's head.

We'll follow blindly where the Maid divine

Shall lead! Her seeress-eye shall lead us on,

And this brave sword shall shield and shelter her!

\section{LA HIRE}

Not e'en a world in weapons shall we fear

When she goes marching on before our hosts.

The God of victory wanders at her side.

Let her, in battle mighty, be our guide!

(All the Knights present raise a din with their lances and advance.)

\section{CHARLES}

Yes, holy Maiden, lead thou on my host, And all my princes shall give heed to thee.

This sword of highest martial power, that late, The crown's field marshal wrathfully returned, Has found in thee a hand more worthy of it. Receive it now, oh holy prophetess, And be henceforth-

\section{JOHANNA}

Not so, oh noble Dauphin!

Not through this instrument of earthly power 
Is victory vouchsafed unto my lord.

I know another sword wherewith I'll conquer.

I will describe it thee, e'en as the spirit

Instructed me. Send forth and have it fetched!

Name it, Johanna.

\section{CHARLES}

\section{JOHANNA}

Fierboys, there in Saint Catherina's churchyard

Is found a vault, wherein much metal lies,

Heaped up from olden loot of victory.

Amid it is the sword, that now shall serve me.

By the three golden lilies shall one know it,

Which on its very blade have been impressed.

Have that sword fetched here for through it shalt thou

be victor.

\section{CHARLES}

Send someone there and do as she hath said!

JOHANNA

And a white banner thou shalt let me carry, Encompassed in a border-seam of purple.

And on this banner let the Queen of Heaven

Be pictured with the lovely Jesus-Child,

As she doth hover o'er the earthly sphere;

For thus the Holy Mother showed it me.

So be it as thou sayest.

\section{Charles}

\section{JOHANNA}

Reverend Bishop,

Upon me lay thy sacerdotal hands

And speak a blessing over me, thy daughter!

1165

(She kneels down.)

ARCHBISHOP

Thou hast been sent God's blessings to dispense

Not to receive them-Go in God's own power!

We are but men, unworthy quite and sinners.

(She arises)

\section{SQUIRE}

A herald's come from England's High Commander.

$$
\text { JoHANNA }
$$

Let him come in, for he is sent by God!

(The King beckons to the Squire, who goes out.) 


\section{ELEVENTH SCENE}

The Herald joins the others.

\section{CHARLES}

What bring'st thou, herald? Say, what is thy charge?

\section{HERALD}

Who is it, who for Charles, the Valois, The Count of Ponthieu, here doth play the spokesman?

\section{DUNOIS}

Thou good-for-nothing herald! low-down boy!

Art thou so insolent to disavow

The King of France upon his own terrain?

The coat-of-arms protects thee, else thou should'st-

\section{HERALD}

The French acknowledge but one single king, And that one dwells within the English lines.

\section{Charles}

Be quiet, cousin! Now, thy message, herald!

HERALD

My noble General, who laments the blood

That has already flowed and still shall flow, Still holds his warrior-sword within its scabbard And ere by storm fair Orleans shall fall, $\mathrm{He}$ offers thee a friendly compromise.

Let's hear it!

\section{Charles}

\section{JOHANNA (steps forward)}

Sire, let me in thy stead

Speak with this herald.

\section{CHARLES}

Do it then, oh Maiden!

Thou shalt decide if it be peace or discord.

$$
\text { JoHANNA (to the Herald) }
$$

Who sendeth thee and speaketh through thy mouth?

\section{HERALD}

The Britains' chief, the Count of Salisbury.

\section{JOHANNA}

Thou, herald, lie'st! That lord speaks not through thee, Alone the living speak, and not the dead. 


\section{HERALD}

My Marshal lives in fulness of sound vigor

And strength, and lives to bring you all destruction.

\section{JOHANNA}

He lived when thou did'st leave, but just this morning

A shot from Orleans stretched him to earth,

As he looked down from tower La Tournelle.

Thou laughest 'cause I distant things reveal?

Believe then not my words but thine own eyes!

His funeral train will soon encounter thee

When thine own feet have borne thee back from here!

Now herald, speak, and say what is thy charge.

\section{HERALD}

If thou dost know to lay what's hidden bare, Then thou dost know it, ere I tell it thee.

\section{JOHANNA}

I have no need to know it, but now hear

Thou mine! And then these words of mine make known

Unto the princes, who have sent thee here!

Oh King of England, and oh ye, the Dukes,

Bedford and Gloucester, regents of the realm,

Give your accounting to the King of Heaven,

For all the blood spilled wantonly. And give

To us the keys of all the towns you've taken

In contradiction to the laws of God!

The Maiden cometh from the King of Heaven

To proffer you or peace or bloody war.

Choose! For I tell you this, that ye may know it:

To you this beauteous France is not assigned

By our Virgin Mary's Son, but Charles,

My lord and dauphin, whom our God awards it,

Will as the king, make entry into Paris,

Accompanied by all Grandees of the realm.

-Now, herald, go! With haste depart from here!

For ere thou hast once more thy camp attained, And brought this news, the Maiden will be there, To plant in Orleans the sign of victory.

(She departs. Everything is in commotion. The curtain falls.) 


\section{SECOND ACT}

A Region surrounded by Crags.

\section{FIRST SCENE}

Talbot and Lionel, English Generals. Philip, Duke of Burgundy. Knights; Fastolf and Chatillon with soldiers and standards.

TALBOT

Here underneath these crags now let us make

A halt and pitch a well-watched camp,

To see if we our fleeing folk can reassemble,

Who in the early panic were dispersed.

Set up a goodly guard and man the heights!

The night, of course, secures us from pursuit,

And if the foe does not possess wings too,

Then I fear not surprise attack. But yet

There's need of caution, for we have to do

With an audacious foe, and are defeated.

(Knight Fastolf departs with his soldiers.)

LIONEL

Defeated, General, say that word no more!

I cannot bear to think that men of France

Have this day seen the Englishman turn tail.

Oh Orleans! Orleans! Grave of our fame!

Upon thy fields lies prostrate England's honor.

A shamefully ridiculous defeat!

Who will believe it in the times to come?

The victors of Poitiers, Crecy

And Agincourt in flight before a woman!

\section{BURGUNDY}

This must console us: We are not by men

O'erwhelmed, but we are conquered by the devil.

TALBOT

The devil of our folly!-Say, Burgundy?

Affrights the rabble's ghost the princes too?

This superstition is a sorry cloak

For your timidity. Your troops fled first.

\section{BURGUNDY}

Not one stood fast. The flight was common lot.

TALBOT

No, Sir! On your flank it had its beginning. 
You rushed headlong into our camp and screamed:

"All hell is loose, and Satan fights for France!"

And thus you threw our troops into confusion.

\section{LIONEL}

You can't deny it. Your flank yielded first.

\section{BURGUNDY}

Because the first attack was levied there.

\section{TALBOT}

The Maiden knew the weak spot of our camp,

She knew just where our fear was to be found.

\section{BURGUNDY}

What? Shall Burgundy bear the blame for failure?

LIONEL

We Englishmen, were we alone, by God,

We never would have lost fair Orleans!

BURGUNDY

No,-for you had ne'er beheld fair Orleans!

Who cleared the way for you into this realm,

Reached out to you the loyal hand of friendship

1265

When you did scale this hostile foreign coast?

Who then did crown your Henry in Paris?

And did subject to him the Frenchmen's hearts?

By God! If this strong arm had never led

You in, you never should have seen the smoke

1270

Ascending from a single hearth in France!

LIONEL

If mighty words alone could do it, Duke, Then you alone had conquered all of France.

\section{BURGUNDY}

You are displeased that Orleans has slipped

Your grasp, and now you vent the venom of

Your wrath on me, your allied friend. Why else

Did Orleans escape save through your greed?

It was prepared to yield itself to me,

You, your envy only, hindered it.

\section{TALBOT}

We did not lay our siege to profit you.

\section{BURGUNDY}

How would it be, if I withdrew my forces? 
LIONEL

Not worse, in truth, than once at Agincourt,

Where we did finish off both you and all of France.

BURGUNDY

But sorely you felt need to win our friendship,

And dearly your vice-regent purchased it.

1285

TALBOT

Yes, dearly, dearly we today have paid

For it at Orleans with our prizéd honor!

BURGUNDY

Don't press it further, Lord, or you might rue it!

Did I desert my sovereign's righteous banners,

And load upon my head a traitor's name

1290

To bear such insults from a foreigner?

What am I doing here, thus fighting France?

If I must serve a person who's ungrateful,

Then I desire it be my native king.

TALBOT

You're now engaged in dealings with the Dauphin;

1295

We know of it. But we shall find the means

To shelter us from treason.

BURGUNDY

Hell and damnation!

Is thus that we are met? Oh Chatillon!

Have all my troops prepare them for departure.

We're going back to our own land.

(Chatillon departs.)

\section{LIONEL}

Luck on your way!

Ne'er was the fame of Britain more resplendent

Than when, with trust in his good sword alone,

He fought without the help of foreign henchmen.

Let each one fight his battles all alone

For it remains eternally true: French blood

And English blood can never mix with honor.

\section{SECOND SCENE}

Queen Isabeau, accompanied by a page, joins the group.

ISABEAU

What must I hear, my Generals? Call a halt! 
What sort of brain-deranging planet is it, That thus befuddles your else normal senses?

Now, when only concord can preserve you,

Will you in hate disperse, and feuding thus

Prepare the way that leads to your own downfall?

I beg you, noble Duke, recall your rash

Command. And you, our Talbot, crowned with fame,

Assuage the friend, whom you have brought to temper! 1315

Come, Lionel, help me persuade to peace

These haughty souls and bring conciliation.

\section{LIONEL}

Not I, my Lady. To me it's all the same.

I think it's thus: Whatever can not stand

Together, it does best if it dissolve.

ISABEAU

What? Does the hocus-pocus art of hell,

To us so fateful in the fight, here too

Still dupe us, sense-befuddled imbeciles?

Just who began the row? Speak!-Noble Lord!

(To Talbot)

Is't you, who so forgot your own advantage,

As to offend our worthy allied partner?

What hope you to perform without his arm?

He built unto your king this present throne,

Supports him still, unseats him when he wills.

His army gives you strength, e'en more his name.

All England, if it poured out all its people

Upon our coasts, would not be able to

Subdue the realm, if it were but united.

For only France alone could conquer France.

\section{TALBOT}

We know the way to honor loyal friends.

To fend against the false, is wisdom's duty.

\section{BURGUNDY}

Who, faithless, will deny a debt of thanks, Fails not to show the liar's brazen front.

ISABEAU

What, noble Duke, could you so far renounce Your princely honor and your sense of shame To lay this hand of yours into the very hand

That slew your father? Were you mad enough 
To have belief in real conciliation

E'en with the Dauphin, whom unto the brink

Of his destruction you yourself have hurled?

1345

So near his fall would you sustain him now

And thus insanely your own work destroy?

Here stand your friends. And your salvation rests

Alone in a firm bond with England.

BURGUNDY

Far is my mind from peace made with the Dauphin,

1350

But this contempt and this high arrogance

Of haughty England I can not endure.

\section{ISABEAU}

Come! Do not take his hasty word amiss.

Grave is the grief that weighs upon the general,

And, as you know, misfortune makes unjust.

1355

Come, Come! Embrace and let me close this rift,

Quick healing it, before it grows eternal!

\section{TALBOT}

What think you, Burgundy? A noble heart

Admits it gladly when o'ercome by reason.

The queen has there a clever word delivered;

Come let this hand-clasp heal that wound of yours

Which by my tongue in reckless haste was cut.

\section{BURGUNDY}

The lady spoke a word quite full of reason, And my just wrath yields to necessity.

\section{ISABEAU}

Good! Now let's seal a new-concluded bond

With one fraternal kiss and may the winds

Waft from our midst all that which has been spoken!

(Burgundy and Talbot embrace.)

LIONEL

(observing the group, ASIDE.)

Luck to the peace established by a Fury!

\section{ISABEAU}

One single battle we have lost, my Generals.

Luck was against us, but do not, for that,

Allow your noble courage to ebb! The Dauphin

Despairs of Heaven's protection, and invokes

The help of Satan's arts; but yet in vain 
Has he surrendered him to his damnation.

And hell itself shall never rescue him.

1375

A conquering maiden leads the hostile troops, Yours I will lead, and I for you shall be

A substitute for prophetess and virgin.

\section{LIONEL}

Madame, go back to Paris! It is our will

To win with goodly weapons, not with women.

1380

\section{TALBOT}

Go, go! Since you are in our camp all goes

Awry, no blessing more is in our weapons.

BURGUNDY

Go! Here your presence fashions naught that's good, The warrior is only vexed by you.

\section{ISABEAU}

(looks at one after the other in astonishment.)

You too, Burgundy? You take sides with these

Ungrateful lords and stand opposed to me?

\section{BURGUNDY}

Go, Go! The soldier loses his good courage

When he believes he's fighting for your cause.

\section{ISABEAU}

I scarce have reestablished peace 'twixt you

Ere you form your alliance aimed at me?

1390

\section{TALBOT}

Go, go! In Heaven's name, madame. We fear

No devil more, when you are once away.

ISABEAU

Am I not your own true confederate?

Is not your cause then also my cause too?

TALBOT

But your cause is not our cause. We are

Engaged in honorable and goodly strife.

\section{BURGUNDY}

I will avenge my father's bloody murder.

This pious duty blesses son-borne weapons.

\section{TALBOT}

But let's be frank! What you do to the Dauphin Is neither good 'fore man nor right 'fore God. 


\section{ISABEAU}

A curse befall him through ten generations!

For he has sinned against his mother's head.

\section{BURGUNDY}

He thus avenged a father and a spouse.

\section{ISABEAU}

He set himself to judge me and my morals.

LIONEL

That was quite disrespectful of a son!

ISABEAU

And he has sent me into banishment.

\section{TALBOT}

That was to consummate the public's voice.

$$
\text { ISABEAU }
$$

A curse befall me if I e'er forgive him!

And ere he rules in his paternal realm-

\section{TALBOT}

You'd rather sell the honor of his mother!

\section{ISABEAU}

You know not, timid souls,

What an offended mother's heart can do.

I love whoever treats me well, and hate

Who injures me, and be it mine own son,

Whom I have borne, the more deserves he hate.

To whom I gave his being, from him I'll rob it,

If he, with ruthless, daring arrogance,

Does injury to the womb that carried him.

You, who are waging war against my son,

You have no right nor reason to despoil him.

How grievous is the debt the Dauphin has

Incurred 'gain you? What pledges has he broken?

The quest for honor, common envy, goads you;

I have the right to hate him. I have borne him.

\section{TALBOT}

Yea, in your vengeance he will feel his mother!

\section{ISABEAU}

You wretched hypocrites, how I despise you, You, who delude yourselves and cheat the world! 
You Englishmen stretch forth your robber-hands

To seize our France, where you have neither right

Nor valid claim to even so much land

1430

As horse's hoof can cover.-And this Duke,

Who lets the good man be reviled, sells out

His Fatherland, inherited from forebears,

Unto his country's foe and foreign master.

But yet your each third word is "Righteousness."

1435

Hypocrisy I scorn. Just as I am,

Let earth's clear eye behold me.

\section{BURGUNDY}

It is true!

Your fame you have maintained with robust spirit.

IsABEAU

I have my passions and as fervid blood

As any woman, and I came as queen

1440

Into this land to live, and not to seem.

Should I be dead to joy, because the curse

Of fate conjoined my vital, happy youth

Unto a consort insane and demented?

More than my life I love my independence,

And he who wounds me here-and yet why should

1445

I quarrel with you here about my rights?

Your sluggish blood flows slowly through your veins,

You know not aught of pleasure, only wrath!

And this Duke here, who through his whole life long

Has wavered 'twixt both bad and good, cannot

With all his heart and soul nor love nor hate.

I'm going to Melun! Give me this man,

(pointing to Lionel)

Who pleases me, for company and amusement.

And then do what you will! I'll ask no questions

Concerning English or Burgundians.

(She beckons to her pages and is about to leave.)

\section{LIONEL}

Rely on this! The fairest Frankish boys

Whom we shall take, we'll send unto Melun.

ISABEAU (coming back.)

To slay with sword you are quite competent,

The Frank alone can speak a compliment.

(She departs) 


\section{THIRD SCENE}

Talbot, Burgundy. Lionel.

Oh, what a woman!

\section{TALBOT}

LIONEL

Your opinion, Generals!

Shall we flee further, or shall we turn back

And by a rapid and a daring stroke

Wipe out the stigma of the present day?

\section{BURGUNDY}

We are too weak, our people are dispersed,

The terror in our army is too recent.

TALBOT

A blind terror only has o'ercome us, The sudden imprint of a single moment, The fear-impression of imagined terror, When nearer seen, will vanish into naught. My counsel, therefore, is, we lead our forces At break of day again across the stream Against the foe.

\section{BURGUNDY \\ Consider-}

\section{LIONEL}

Allow. There's nothing here to be considered.

We must in haste regain what we have lost,

Or be disgraced in all eternity.

If you will

\section{TALBOT}

It is resolved. Tomorrow we attack.

And to destroy this phantom-cause of terror, That has deluded and unmanned our forces, Let us in personal encounter measure Ourselves against this virgin-feigning devil! If she stands up before our valiant sword, Well, then, for the last time she's done us harm, If she stands not, and surely she will shun An earnest fight, our host is disenchanted.

\section{LIONEL}

So be it! And to me, my chief, assign This easy play of arms, where flows no blood! 
For I intend to take that ghost alive, And 'fore the Bastard's eyes, her paramour's, I'll carry her in mine own arms across

Into the British camp to cheer our troops.

Now promise not too much!

BURGUNDY

\section{TALBOT}

If I get at her,

I think not all too gently to embrace her.

Now come, to quicken all too tired nature

By means of gentle, recreating slumber, 1495

And then break camp at morning's reddening glow!

(They withdraw.)

\section{FOURTH SCENE}

Johanna with her banner, wearing helmet and breastplate; otherwise attired as a woman; Dunois, La Hire, Knights and Soldiers show themselves above on a road on the crags. They pass by in silence and appear immediately thereafter on the stage.

\section{JOHANNA}

(to the Knights who surround her, while the procession above continues.)

The wall is scaled and we are in the camp!

Now cast from you the cloak of secret night, Which up to now has veiled your silent march.

And to the foe make known your dreaded presence

By your loud battle-cry: "God and the Virgin!"

ALL

(cry aloud amid the wild clang of weapons.)

God and the Virgin!

(Drums and trumpets.)

\section{SENTRY (behind the scene)}

The foe! the foe! the foe!

$$
\text { JOHANNA }
$$

Now torches here! Throw fire in their tents!

Let raging flame intensify dismay

And, threatening round about, let death embrace them!

(Soldiers hasten forth. She wishes to follow.) 
DuNors (holds her back.)

Thy part thou hast accomplished now, Johanna.

Into the middle of the camp hast led us.

The foe thou hast delivered to our hands

But from the field of strife now stay away

And leave to us the bloody consummation!

\section{LA HIRE}

The way to triumph show unto our host, Before us bear in your pure hand the banner. But do not take the sword, the deadly sword, Thyself, tempt not the fickle god of battles, For blind and with no mercy he holds sway.

\section{JOHANNA}

Who dares to bid me halt? Who dares prescribe

Unto the spirit leading me? The arrow

Must fly where'er the archer's hand directs.

Where danger is, there must Johanna be.

Nor now, nor here am I ordained to fall.

The crown I first must see upon my monarch's head.

This life from me shall not be riven.

Till I fulfill the order God has given

(She goes out.)

\section{LA HIRE}

Come, Dunois! Let us track our heroine!

And lend our valiant breasts to be her shield!

(They depart.)

FIFTH SCENE

English Soldiers flee across the stage; then Talbot.

First SOLDIER

The Maiden! In the middle of our camp!

SECOND SOLDIER

Impossible! No, never! How came she to camp?

THIRD SOLDIER

Through the air! The devil helps her!

FOURTH AND FIFTH SOLDIER

Flee! Flee! We all are marked for death! (They depart.)

\section{TALBOT (enters.)}

They hear me not-they will not stand with me! 
Dissolved are all the bonds of discipline,

As if old hell its legions of damned souls

Had spewed on us, a reeling madness drags

Both valiant men and cowards brainlessly

Away; not e'en a petty party can

1535

I hold against the flood-tide of the foe,

Which waxing wavelike inundates our camp!

-Am I the only sober soul, when all

Around me must in fever's frenzy rage?

Before these Frankish weaklings so to flee,

Whom we in twenty battles have o'erwhelmed!

1540

Who is she then, this uncontrollable,

This terror-goddess, who so quickly turns

The luck of battle; and a timid herd

Of coward roes transforms to fighting lions?

A sorceress who plays her studied role

Of heroine, shall frighten proven heroes?

A wench has snatched from me all fame of battle?

SOLDIER (rushes in.)

The Maiden! Flee! Flee! Flee, General!

TALBOT (strikes him down.)

Flee to hell

Yourself! Him shall this very sword transfix,

1550

Who speaks to me of fear and faint-heart flight!

(He departs.)

\section{SIXTH SCENE}

The prospect opens. One sees the English camp completely in flames. Drums, flight and pursuit. After a while Montgomery enters.

\section{MONTGOMERY (alone.)}

Where shall I flee to? Foes around about and death!

Here our enraged leader, who, with threatening sword, Retarding flight, dares drive us straight toward our death.

There the Dreadful One, who ruinous 'round herself

Like burning fire rages, and around there is

No bush to hide me and no cave of sure retreat.

Oh were I never shipped across the sea to here,

Oh, I, unfortunate! Whom idle dream deranged

To search for cheaply purchased fame in Frankish wars. $\quad 1560$

And now destructive destiny is leading me 
Into this bloody, murderous fight.-Were I but far From here, at home still on the Severn's blooming bank, Secure within my father's house, wherein my mother In grief remained, and my sweet, tender bride-to-be!

(Johanna makes her appearance in the distance.)

Woe's me! What see I? There appears the female terror! From flaming fire-brands dull glowing she mounts up, As from the jaws of hell a spectre of the night Might rise.-Where can I flee? She seizes me already And, with her eyes of fire, casts from afar at me The never-failing captivation of her glance. Around my feet is firm and faster wrapped a skein Of magic that so fetters them that they deny Me flight! And I must gaze, however much my heart Against it struggles, at that fatal apparition!

(Johanna advances several steps toward him and then remains standing again.)

She comes! I will not wait until this form so grim Attacks me first! Imploring, I'll embrace her knees, And for my life I shall beseech; she is a woman; Might I perchance through show of tears cause her to soften!

(As he is about to approach her, she walks rapidly toward him.)

\section{SEVENTH SCENE}

Johanna.

Montgomery.

JOHANNA

Thou art condemned to death! A British mother 'gendered 1580 thee!

MONTGOMERY (falls at her feet.)

Desist, thou fearful one! Do not transfix a man

Who's undefended! Sword and shield I've cast away, And at thy feet I sink to earth, defenceless, pleading.

Leave me the light of life and take some ransom money!

Rich in possessions lives at home my father still

In beauteous Wales, there, where the Severn's serpentine

Doth roll its silver stream amid the verdant meadows, And fifty villages confess his overlordship.

With richest gold he will absolve his lov'd son, When he's aware I'm still alive in Frankish camp. 


\section{JOHANNA}

Misguided fool! Lost soul! Into the Maiden's hand

Thou now art fallen; the destructive hand from which

Nor rescue nor redemption is to be expected.

If thy ill luck had put thee in the crocodile's

Main power, or in the spotted tiger's mighty claws,

If thou hadst stolen the mother-lion's new-born brood,

Thou couldst perchance have found both pity and compassion,

But deadly is encounter with the virgin.

For to the spirit-realm, the strict, inviolable,

Am I by awful, binding contract obligated

To slaughter with the sword each living thing, whate'er

The god of battle fatefully doth send my way.

\section{MONTGOMERY}

Frightful is thy speech, but yet thy look is mild, Not dreadful art thou to behold from close at hand.

My heart doth draw me close unto thy lovely form.

$\mathrm{Oh}$, by the gentleness of thy mild, tender sex

I beg of thee! Have pity on me still a youth!

\section{JOHANNA}

Do not adjure me by my sex! Don't call me woman!

Just as the incorporeal spirits, who woo not

In human wise, I join me not to any sex

Of humans, and this, my armor, covers up no heart.

\section{MONTGOMERY}

Oh, by the holy all-prevailing law of love

To which all hearts pay homage, I do adjure thee!

At home I left behind a darling bride-to-be,

Fair as thou art, ablowing in the charm of youth.

She tarries, waiting for her lover's safe return.

Oh, if thou ever hop'st that thou shalt love, and hopest

Through love to be made glad, then part not cruelly

Two hearts that by the holy bond of love are tied!

\section{JOHANNA}

Thou dost invoke but earthly foreign deities,

To me not holy, nor to be adored. I know

Naught of the bonds of love with which thou'd conjure me.

And never shall I learn to know its idle service.

Fend for thy life's defense, for death is calling thee! 


\section{MONTGOMERY}

$\mathrm{Oh}$, then have mercy on my sorrow-stricken parents, 1625

Whom I have left at home! Yea, surely thou hast, too, Forsaken parents who for thee are plagued with sorrow.

\section{JOHANNA}

Unhappy man! And thou remind'st me now of this:

How many mothers of this land are childless now;

How many tender children, fatherless; how many

Expectant brides are widowed by these deeds of yours?

So England's mothers too may now experience

Despair and make acquaintance with the tears

Which France's sorrow-stricken wives ere now have wept.

MONTGOMERY

$\mathrm{Oh}$, hard it is to die unwept on foreign soil.

\section{JOHANNA}

Who called you to this foreign land to lay in waste The blooming labor of our fields, to chase us from

Our native hearth, and throw the firebrands of war

Into the peaceful sanctuaries of our cities?

Ye dreamed already in your heart's vain phantasy

To plunge the free-born Frenchman into serfdom's shame And this great land, as if it were a little boat,

To fasten firmly to your haughty ocean vessel!

Ye fools! The royal coat-of-arms of France hangs on The throne of God. And sooner ye might tear a star

From Heaven's wain than pluck a village from this realm, Inseparably, eternally united. The day

Of vengeance has arrived. And ye no more while living Shall e'er retrace the reaches of the holy sea,

Which God has set betwixt us as our lands' partition. And which ye have transgressed in your frivolity.

MONTGOMERY (releases her hand.)

Oh, I must perish! Groveling now I'm grasped by death.

$$
\text { JOHANNA }
$$

Die, friend! Why tremble thus so timidly 'fore death, The inescapable event?-Behold me! Look!

I am but a mere maiden, born a shepherd girl.

This hand has never known the wont to wield the sword. The innocent and pious shepherd staff it bore.

But torn away from fields, that were my native home, From father's bosom and my sisters' loving breast, 
Must I here, I must-a voice divine impells me, not

1660

My own desires-a bitter grief for you, for me

No joy, a spectre of dismay, athrottling go

And scatter death abroad, and be, at last, its victim.

For I no day of joyous going home shall ever see.

To many of your countrymen I'll still bring death,

1665

And many widows shall I make, but finally I,

Myself, shall perish and shall thus fulfill my fate.

-Fulfill thou likewise thine! With vigor grasp thy sword.

And for the sweetest prize of life let us contend.

MONTGOMERY (arises).

Well, if thou art a mortal, as I am, and arms

Can wound thee, then, it may be destined for my arm,

By sending thee to hell, to end all England's woe.

In God's all-gracious hands I lay my destiny.

Call thou, accurséd one, thy hellish spirits now

To stand by thee! And now defend thy right to live!

(He seizes shield and sword and presses in on her. Martial music resounds in the distance. After a short duel Montgomery falls.)

\section{EIGHTH SCENE \\ JoHANNA (alone).}

To death thy foot did bear thee. -Fare thee well!

(She walks away from him and remains standing in thought.)

Exalted Virgin, thou in me art working wonders!

Thou dost supply my peaceful arm with power,

This heart of mine thou armest with unyieldingness.

With pity melts my soul, my hand doth quake,

As if it broke into a temple's holy pile,

To wound the blooming body of my foeman;

The shining blade of iron alone makes me to shudder. But when there's need of it, just then I have the power, And, never erring in my trembling hand, the sword

Directs itself as if it were a living spirit.

\section{NINTH SCENE}

A Knight with a closed visor. Johanna.

\section{KNIGHT}

Accurséd one! Thine hour hath arrived. 
I've sought thee on the far-flung field of battle.

Destructive phantom! Get thee straightway back

To hell, from whence thou hast to us ascended!

1690

JOHANNA

Who art thou, whom thy evil angel sent

To 'counter me? Like to a prince's is

Thy bearing, nor as British dost thou seem,

For the Burgundian badge betrays thy state.

In face of it my sword's tip dips to earth.

1695

KNIGHT

Vile outcast, thou deservest not to fall

Beneath a prince's noble hand. The ax

Of hangman ought to sever from thy torso

Thy damnéd head, and not the daring dagger

Held by the royal Duke of Burgundy.

1700

$$
\text { JOHANNA }
$$

Thou art, forsooth, this royal Duke himself?

KNIGHT (opens his visor).

I'm he! Oh wretch, now tremble and despair!

Now Satan's arts shall shelter thee no more.

Thou hast till now but weaklings overcome.

A man stands facing thee.

TENTH SCENE

Dunois and La Hire join them.

\section{DuNOIS}

Turn, Burgundy!

Now fight with men and not with virgin women!

\section{LA HIRE}

We shall protect the seeress's holy head.

First must thy dagger penetrate this breast-

\section{BURGUNDY}

It's not this amorous Circe that I fear,

Nor you, whom she so shamefully has transformed.

Oh, Bastard, blush, and shame on thee, La Hire,

That thou thy ancient valor so degradest

To arts of hell, and makest now thyself

The shield and page-boy of this devil's-wench!

Come on! I challenge all! That man despairs

Of God's safe shield, who flees unto the devil. 
(They prepare to fight; Johanna steps between them.)

Hold up! Hold up!

JOHANNA

BURGUNDY

Thou tremblest for thy lover?

Before thine eyes shall he-

(He presses in on Dunois.)

JOHANNA

Hold up, I say!

Part them, La Hire! Here no Frankish blood shall flow!

Nor shall this strife by sword-play be decided.

Another way is in the stars decreed.

Now separate, I say!-Hear and respect

The spirit which pervades me, speaks through me!

\section{DuNOIS}

Why dost thou stay my now uplifted arm

And halt the bloody verdict of my sword?

1725

The blade is drawn and now it strikes the blow

Which shall avenge and reconcile our France.

\section{JOHANNA}

(Places herself between them and separates the parties by a wide interval.)

(To the Bastard.)

Step to the side!

(To La Hire).

Remain there, standing fixed!

I have a word to speak now with the Duke.

(After all is quiet.)

What wilt thou do, oh Burgundy? Who is

1730

The foe thy murderous glance with yearning seeks?

This noble prince is France's son as thou,

This valiant is thy native friend and ally,

And I'm a daughter of thy fatherland.

We all, whom thou dost strive to extirpate,

1735

Belong among thy people and, our arms

Are open wide to welcome thee, our knees

Prepared to do thee honor, and our sword

Against thee has no point. And honorable

To us thy visage; e'en in hostile helm,

It bears the loyal features of our king. 


\section{BURGUNDY}

With flatt'ring sound of thy sweet eloquence Wilt thou, oh Siren! lure thy victim on.

Thou, cunning one, shalt make no fool of me.

My ear's prepared against thy speech's snares,

The fire-arrows of thine eyes glide off

Upon the goodly armor of my bosom.

Now, to arms, Dunois!

With blows, and not with words, let us fight on!

\section{DUNOIS}

First words, and later blows! Art thou afraid

Of words? That too is cowardice, that too

Is the betrayer of an evil cause.

\section{JOHANNA}

It's not despotic need that drives us here

Unto thy feet, and not as suppliants

Come we to thee.-Just look around thee here!

1755

In ashes lies the camp of English might

And with your dead the field is overstrewn.

Thou hear'st the Frankish battle-trumpet sounding.

God hath decided, victory is ours.

The freshly broken bough of shining laurel

We are prepared to share now with our friends.

Oh, come to us! Come, noble fugitive!

To us, where right and victory prevail.

E'en I, God's messenger, extend to thee

In sister's wise my hand. I wish to save

And draw thee over to our righteous side.

The Heavens are for France, and Heaven's angels, Although thou see'st them not, fight for our king.

With lilies are they, each and all, adorned.

Our cause is shining white, as is this banner.

The pure Virgin is our spotless symbol.

\section{BURGUNDY}

Intriguing is the lie's deceptive word, And yet her speech is like that of a child. If evil spirits lend to her their words, Then they triumphant copy innocence.

I will no longer listen! To your weapons! My ear, I mark, is weaker than my arm.

Thou callest me enchantress, unto me 
Ascribest hellish arts. Is making peace, Dispelling hate, the work of hell? And from

The everlasting pool does concord come?

What is there guiltless, holy, humane, good, If not the fight to save the fatherland?

Since when is nature so in conflict with

Itself, that Heaven doth the righteous cause

1785

Desert, and that the devil doth defend it?

But if that which I say to thee is good,

Where else but from above could I procure it?

Who could have come into my fold of sheep

To visit me, a childish shepherd maid,

And consecrate me to the king's affairs?

I've never stood before exalted princes,

The art of speech is foreign to my tongue.

But now, since I have need thereof to move thee,

I have discernment, knowledge of high things,

1795

The fate of kings and destinies of countries

Lie clear as suns before my childish gaze,

And in my mouth I bear a thunderbolt.

\section{BURGUNDY}

(vividly moved, directs his eyes toward her and observes her with astonishment and emotion.)

What ails me? What is happening? Is't a god,

Who in my deepest bosom turns my heart?

1800

She's no deceit, this touching, stirring form!

No! No! if I'm through magic's might made blind,

Then it is wrought alone through heavenly power.

My heart informs me she is sent by God!

JOHANNA

He's touched, he's moved! I have not pled in vain;

1805

The thunder-cloud of anger melts away

From off his brow 'mid dripping tears like dew,

And from his eyes, emitting rays of peace,

The golden sun of feeling now breaks forth.

Away the weapons! Press now heart to heart!

He weeps, he is persuaded, he is ours!

(Her sword and banner sink from her hand, she hastens to him with outstretched arms and embraces him with passionate exuberance. La Hire and Dunois let their swords fall and hasten to embrace him.) 


\section{THIRD ACT}

Royal Headquarters at Chalons on the Marne.

FIRST SCENE

Dunois and La Hire.

\section{DUNoIs}

We were both cordial friends and war-time brothers, We raised our arm to serve the common cause, And held together fast in dearth and death.

Let not the love of woman rend this bond

That has survived each by-gone change of fortune.

Prince, hear me speak!

\section{LA HIRE}

\section{DUNOIS}

You love the wondrous Maiden,

And I am well aware what you intend.

You think to go now hot-foot to the king

And there beseech the Maiden as a present

1820

Unto yourself. And for your acts of valour

He can't deny to you the well-earned prize.

But know-e'er in another's arms I shall

Behold her-

$$
\text { Hear me, Prince! }
$$

$$
\text { LA HIRE }
$$

\section{DUNOIS}

It's not the eyes'

Quick flighty passion that attracts me to her.

My own unconquered sense a wench ne'er has

Aroused until I saw this wondrous one, Whom a decree of God intends to be A saviour for the realm, a wife for me. And in that moment to myself I swore

A holy oath to take her as my bride.

For only the strong woman can become

The friend of the strong man. My glowing heart

Doth yearn to rest upon a breast its equal, One that can 'compass and endure its strength.

LA HIRE

How could I dare it, Prince, my weak deserts With your great name's heroic fame to measure? 
Where Count Dunois has entered in the lists

There every other challenger must yield.

But yet a lowly shepherd girl cannot

1840

Stand worthily as consort at your side;

The kingly blood that courses through your veins

Will surely scorn such lowly intermixture.

\section{DuNOIS}

She is a child of holy nature's Gods

As I myself, and is by birth my equal.

1845

Should she dishonor any prince's hand,

Who is herself the bride of pure angels,

Who wreathes her head with glowing radiance,

Which brighter shines than any earthly crowns,

Who sees all greatness, highness of this earth

Lie petty underneath her very feet?

For all the princely thrones, placed one upon

The other, and even to the stars built up,

Could not attain the height at which she stands

In her angelic majesty.

$$
\text { LA HIRE }
$$

The sovereign must decide.

\section{DUNOIS}

Decides it! She has liberated France,

No, she herself

And she herself must freely give her heart.

Here comes the king!

\section{LA HIRE}

\section{SECOND SCENE}

Charles. Agnes Sorel. Du Chatel, Archbishop and Chatillon join the others.

\section{Charles (to Chatillon)}

He comes! He wishes to salute me as 1860

His sovereign, as you say, and pay me homage?

\section{Chatillon}

Here, Sire, in thine own, thy royal town, Chalons, my lord, the Duke desires to prostrate Himself before thy feet. He ordered me To greet thee as my master and my king.

He follows at my heels and soon draws near. 
SOREL

He comes! Oh splendid sunshine of this day, Which brings us pleasure, peace and e'en placation!

CHATILLON

My lord will come with full two hundred knights,

He at thy feet will sink upon his knees;

But he expects that thou wilt not permit it,

But as a cousin friendly wilt embrace him.

Charles

My heart's aglow to beat against his own.

CHATILLON

The duke requests that of the ancient feud

There be no mention, even with one word,

Upon the first return.

\section{Charles}

1875

In Lethe be the past. And now we hope

To see but happy days in times to come.

\section{CHATILLON}

Those who have fought for Burgundy shall be

Included in the terms of the placation.

CHARLES

I shall, in this wise, make my kingdom double!

Chatillon

And Isabeau, the queen, if she accepts, Shall be included in the terms of peace.

\section{CHARLES}

She wages war on me, not I on her.

Our strife shall cease, as soon as she shall end it.

ChatilloN

Twelve knights shall be assurance for thy word.

CHARLES

My word is sacred.

\section{Chatillon}

And the Archbishop

Shall share a sacred host between both you and him

As pledge and seal of honorable placation.

CHARLES

So be my share of everlasting bliss 
As clasp of hand and beat of heart are one.

What other pledge demands the duke to boot?

Chatillon (with a look at Du Chatel)

Here see I one, whose very presence here

Could but lend poison to the primal greetings.

(Du Chatel departs in silence.)

\section{CHARLES}

Go, Du Chatel! Until the duke can bear

The sight of thee, canst thou remain concealed!

(He follows him with his eyes, then hastens after him and embraces him.)

Thou righteous friend, wert willed to do still more

Than this to get me peace!

(Du Chatel departs.)

\section{Chatillon}

The other points this instrument doth name.

\section{ChARLES (to the Archbishop.)}

Bring it to pass! We will approve it all.

To win a friend we hold no price too high.

Go, Dunois! Take a hundred noble knights

Along, and fetch the duke in friendly fashion.

Our troops shall all bewreath themselves with branchlets

In order to receive their brethren.

Let the whole town adorn it for a feast, And all the bells ring out the proclamation That France and Burgundy are now one nation.

(A Squire enters. Trumpets are heard.)

Hark! What's the meaning of the trumpets' call?

SQUIRE

The Duke of Burgundy now makes his entry.

(Exit)

DunoIs (departs with La Hire and

Chatillon.)

Up! To meet him!

Charles ( $t o$ Sorel).

My Agnes weeps! I, too, do almost lack

The strength to carry out the coming scene.

How many victims had to fall in death

Before we two could meet in peace again!

But every storm at last abates its wrath, 
And day succeeds to deepest night. And when The time arrives, the latest fruits grow ripe!

ARCHBISHOP (at the window).

The Duke can scarcely in the mighty throng Assert himself. They lift him from his horse, They kiss his mantle and his very spurs.

\section{CHARLES}

It is a goodly folk, that in its love, As in its hate, is quick inflamed.-How quick Is now forgot that even this same duke Hath slaughtered both their fathers and their sons.

The moment swallows an entire life!

Be calm, Sorel! For thy intensive joy Might be for him a thorn to prick his soul.

Naught here shall either shame him or aggrieve him.

\section{THIRD SCENE}

Duke of Burgundy. Dunois. La Hire. Chatillon and two additional Knights from the Duke's retinue. The Duke remains standing at the entrance; the King moves toward him; immediately Burgundy comes closer, and at the moment when he is about to kneel, the King receives him into his arms.

\section{CHARLES}

You have surprised us.-It was our intent

To come to fetch you, but your steeds are fast.

\section{BURGUNDY}

They brought me to my duty.

(He embraces Sorel and kisses her on the forehead.)

With your leave,

Fair cousin! That's our lordly right in Arras,

And no fair woman ever dares deny

The practice of this rite.

\section{ChaRLes}

Your court, they say,

Is seat of chivalry and market place,

Where all that's beautiful must be in stock.

\section{BURGUNDY}

We are a merchandizing folk, my King. Whate'er delicious grows beneath the heavens, For show and for enjoyment is displayed 
Upon our mart at Bruges. The highest though

Of all our wares is that of woman's beauty.

SOREL

Though woman's fealty rates a higher price,

But is not seen upon the market place.

\section{ChARLES}

You stand in bad repute and libel, cousin,

That you revile what's woman's highest virtue.

\section{BURGUNDY}

Such heresy will be its own worst scourge.

Hail you, my King! Your heart has early learned,

What my wild life has taught me only late.

(He notices the Archbishop and extends his hand to him.)

Most reverend minister of God! Your blessing!

1950

One meets you ever in the proper place.

Whoe'er seeks you must walk in righteousness.

ARCHBISHOP

My Lord may call me when He will; my heart

Is full of joy, and I can gladly part,

Since mine own eyes have now beheld this day!

1955

BURGUNDY (to Sorel)

They say you have bereft you of your jewels

To fashion from them weapons aimed at me?

What? Are you thus so martially intent?

But now our quarrel is past, and all is found

Again which once, it seemed, was lost.

Your jewelry has found its way back home.

For war against me it was once ordained,

Now take it from my hand as token of peace.

(He receives from one of his attendants a jewelcasket and hands it over to her opened. Agnes Sorel looks in astonishment at the King)

\section{CHARLES}

Accept the gift. It is a twofold precious pledge

of fairest love to me and reconciliation.

\section{BURGUNDY}

(While fixing in her hair a diamond rose).

Why is it not the royal crown of France?

With heart that's even thus inclined I would

Be glad to fix it on this lovely head. 
(Pressing her hand significantly.) And-count on me, if you sometimes should be In need of friend!

(Agnes Sorel, breaking out in tears, steps aside, also the King, struggles against great emotion. All the bystanders look with feeling at the two princes.)

\section{BURGUNDY}

(after he has looked at them all, one after the other, he throws himself into the arms of the King.)

Oh, my dear King!

(At the same moment the three Burgundian knights hasten to Dunois, La Hire and the Archbishop. They embrace each other. Both Princes remain for a time speechless in each other's arms.)

You could I hate? You could I e'en renounce?

Still! Still! No further!

\section{CHARLES}

\section{BURGUNDY}

And this Englishman

Could I e'en crown! Swear fealty to this stranger!

\section{CHARLES}

Forget it! All is now forgiven! All This single moment has wiped out. It was

Our fate and an unhappy constellation!

$$
\text { BURGUNDY (clasps his hand). }
$$

I'll make amends! Believe me, that I will.

For all your suff'ring, you'll be recompensed, And your entire kingdom you'll receive

Again, and not one village shall be lacking!

\section{ChARLES}

We are united. I now fear no foe.

\section{BURGUNDY}

Believe 'twas not with happy heart that I

Bore arms against you. If you only knew-

Why did you not send this one here to me?

(Pointing to Sorel.)

Her tears I'd ne'er been able to resist.

Now shall no power of hell divide us more

Since we have closed each other to our heart! 
I now have found a place that's truly mine;

Upon this heart my wandering journey ends.

ARCHBISHOP (steps between them).

You are united, Princes! France now mounts,

Again made young, a Phoenix, from its ashes.

A pleasant future now smiles down on us.

The country's grievous wounds will heal again,

1995

The villages, laid waste, the cities too,

Again shall rise more radiant from their rubble,

The fields shall deck themselves anew with green,

But those, who fell as victims of your feuding,

The dead, arise no more; the tears that flowed,

Because you were in strife, are wept, and thus

2000

Remain! The coming generation soon

Will flourish, but the past was misery's prey.

The grandchild's joy will not revive his fathers.

These are the fruits of your fraternal feud.

2005

Let that give you a lesson! Fear the sword's

Divinity, ere from the sheath you draw it!

The mighty man can unleash war; but, not

Instructed as the hawk, to fly back from

The air unto the hunter's hand, heeds not

2010

That savage god the call of human voice.

Not twice at the right moment as today

Comes forth at the saviour's hand from out the clouds.

\section{BURGUNDY}

Oh Sire! At your side an angel dwells.

Where is she? Why do I not see her here?

\section{CHARLES}

Where is Johanna? Wherefore is she missing

At this most festal, happy point of time,

Which she did grant us?

\section{ARCHBISHOP}

Sire! The holy Maiden

Loves not the quiet of the leisure court,

And if divine command call her not forth

Into the light of day, then she avoids,

Abashed, the idle gaze of common eyes.

Forsooth she doth converse with God, when she

Is not in deed concerned for France's welfare;

For in her footsteps always follow blessings. 


\section{FOURTH SCENE}

Johanna joins the others.

She is in armor but without helmet, and is wearing a wreath in her hair.

\section{CHARLES}

Thou comest as a priestess 'decked, Johanna,

To consecrate the bond that thou hast formed?

BURGUNDY

How dreadful was the Maiden in the fight,

And how, in peace, so radiant with charm!

Have I redeemed my pledge, Johanna, and

2030

Art thou content? Do I deserve thy sanction?

\section{JOHANNA}

Unto thyself, thou hast done greatest favor.

Now thou art radiant in a blessed light,

Who formerly, in blood-red, sombre glow,

A moon of terror hung there in the heavens.

(Looking around.)

2035

Much noble knighthood find I here assembled,

And all their eyes are glistening bright with joy.

One single sad one only I've encountered,

Who must conceal himself, while others cheer.

\section{BURGUNDY}

And who is conscious of such grievous guilt,

That of our favor he must need despair?

JOHANNA

May he draw near? Oh, answer that he may!

Make thy deserts complete. Conciliation

Is naught, unless it free the heart completely.

One drop of hate, that in the cup of joy

2045

Remains, transforms the blessed draught to poison.

So bloody be no crime that Burgundy

Upon this day of joy might not forgive it!

\section{BURGUNDY}

Ah, now I understand!

JOHANNA

And wilt forgive?

Thou wilt, oh Duke?-Come in now, Du Chatel! 2050

(She opens the door and leads Du Chatel in; the latter remains standing at a distance.)

The Duke with all his enemies, with all, 
Is reconciled, and with thee too.

(Du Chatel comes several steps nearer and attempts to read the Duke's eyes.)

\section{BURGUNDY}

What makest thou

Of me, Johanna? Knowest, what thou askest?

\section{JOHANNA}

A gracious master throws his portals wide

For all the guests, and no one is excluded; 2055

Free, as the firmament surrounds the world, So must his grace embrace both friend and foe. The sun sends forth its rays impartially

To all the reaches of infinity,

In equal measure Heaven pours forth its dew 2060

On all the thirsting things that wax and grow.

Whate'er is good and comes down from above

Is meant for all and has no reservation.

But in the folds and crooks, there darkness dwells.

\section{BURGUNDY}

Oh she can shunt me 'round just as she wills. 2065

My heart is weak as wax within her hand.

-Embrace me, Du Chatel! I pardon you.

Ghost of my father, be not wroth, if I

In friendship clasp the hand that murdered thee.

Ye gods of death, ascribe not to my reckoning,

2070

That I now break my awful oath of vengeance.

With you down there in the eternal night

No heart beats more, there everything's eternal,

All stands immobile, fast-but otherwise

Is it up here, within the sunlight's rays.

2075

The mortal man, who is alive and feels,

Is easy victim of the mighty moment.

\section{Charles (to Johanna)}

What have I not to thank thee for, high Maiden!

How prettily thou hast redeemed thy word!

How quickly all my destiny transformed!

My friends thou hast won back to me, my foes

Hast plunged into the dust, and from my cities

Torn off the foreign yoke. For thou alone

Accomplished all! But speak: What's thy reward? 


\section{JOHANNA}

Be ever human, Sire, in fortune as

Thou wast in failure. On the peak of power

Forget not what a friend avails in need;

In thine humiliation thou hast learned it.

Deny not to the lowest of thy people

Thy mercy nor thy justice, for to thee

God called a saviour from the herd. Thou shalt

Assemble all of France beneath thy sceptre,

And be the seed of great and princely scions.

And those who follow thee will shine more brightly

Than those who went before thee on the throne.

2095

Thy stem shall bloom as long as it preserves

Its love within its people's heart.

But pride alone can lead it to its fall,

And from the lowly huts, whence now has come

To thee the saviour, threatens mystically

Unto thy guilt-bespotted heirs destruction!

BURGUNDY

Enlightened Maiden, whom the Lord inspires,

If with thine eyes thou peerest in the future,

Then tell me too of mine own stem! Will it

Extend its majesty as it began?

JOHANNA

Burgundy! To the level of the throne

Hast thou raised up thy seat, and thy proud heart

Still higher strives. It lifts into clouds

Thy bold-built house. But from above

A hand will soon command its growth to halt.

But fear not thence the downfall of thy house!

It shall live on in brilliance through a maiden, And sceptre-bearing sovereigns, shepherds of

Their peoples, shall be the flower of her womb.

And they shall lord it on two mighty thrones

And write the laws of all the known world

And of a new one, which the hand of God

Still hides behind the seas unploughed by ships.

\section{CHARLES}

Oh speak, if it the Spirit has revealed, Will this new bond of amity, which we 
Renewed, in distant ages too unite Our sons?

JoHANNA (after a moment of silence).

Ye kings and rulers of the earth!

Have fear of discord! And awake not strife

Out of its cavern, where it sleeps; for once

Aroused, it slow reverts again to tameness.

A progeny it gets, a brood of iron,

And firebrand ignites succeeding brand.

Demand to know no more! Rejoice now in

The present! Let me calmly still conceal

The future!

\section{SOREL}

Holy Maiden, thou explorest

My heart. Thou krow'st if it aspires to empty grandeur.

To me grant too a pleasing oracle.

\section{TOHANNA}

To me the Spirit shows but great events.

Thy destiny abides in thine own breast.

\section{DUNOIS}

But what will be the fate of thee, thyself,

Exalted Maiden, whom high Heaven loves?

2135

For thee, in sooth, on earth blows fairest fortune.

Since thou art both so pious and so holy.

JOHANNA

One's fortune dwells in God's eternal bosom.

ChaRles

Thy fortune be henceforth thy sovereign's care!

2140

For I will make thy name be glorified

In all of France; and latest generations

Shall call thee blessed-and at once I shall

Accomplish it. Kneel down!

(He draws his sword and touches her with it.)

And now stand up

A noble woman! I, the King, do raise

Thee from the dust of thy own humble birth-

And in their graves thy fathers I ennoble.

The lily in thine armor thou shalt wear,

And be of equal birth with e'en the best

In France. None but the royal blood of the

Valois shall be more noble than thine own! 
The greatest of the great shall feel himself As honored by thy hand. My care shall be

To get thee wed unto a noble husband.

Dunors (steps forth).

My heart elected her when she was lowly. 2155

The new-won honor that shines 'round her head

Exalts not her deserts nor yet my love.

Here, in the presence of my sovereign lord

And of this holy bishop, I extend

To her my hand as to my princely consort,

2160

If she but holds me worthy to receive her.

CHARLES

Resistless Maiden, wonder thou dost heap

On wonder! Yes, I now believe that naught's

Impossible to thee. Thou hast subdued

This haughty heart, that until now spoke scorn

2165

To love's great might.

LA HIRE (steps forward). Johanna's fairest gem,

Know I her rightly, is her modest heart.

The homage of the greatest she deserves,

Yet ne'er will she raise up her wish so high.

She strives not giddily for earthly grandeur.

The true affection of an honest nature

Suffices her, as does the quiet lot,

That I now proffer her with this my hand.

\section{CHARLES}

Thou too, La Hire? Two distinguished wooers,

Alike in martial fame and hero's virtues!

Wilt thou, who reconciled my foes to me,

My realm united, part my dearest friends?

But one of you alone can e'er possess her,

And I esteem each worthy of the prize.

So speak thou, for thine heart must here decide.

SOREL (comes nearer).

I see the noble Maiden is surprised, And bashful shame lends color to her cheeks. Now give her time to ask her heart's advice, To speak confiding with some female friend, And loose the seal unto her fast-locked breast. Now is the moment come, when even I 
May sisterly approach this sterner virgin, And offer her my loyal, secret bosom.

So let us first deliberate as women The womanly affair; and you await 2190

What we shall then conclude.

ChARLES (about to depart). So be it!

JOHANNA

Not thus, my lord! What caused my cheek to color

Was my confusion, not my stupid shame.

I've naught that I'd confide unto this noble lady, That I would be ashamed to tell you men.

I'm highly honored by these good knights' choice,

But I did not desert my sheep and pastures

To hunt for empty, earthly majesty;

Nor yet to twine a bride's wreath in my hair,

Did I put on this brazen coat-of-mail.

2200

I have been called for quite another work.

The pure virgin only can achieve it.

I am the warrior of the highest God,

And cannot be the spouse of any man.

\section{ARCHBISHOP}

To be the loving partner of a man

Is woman born; when she to nature harkens, Then she most worthily is serving Heaven. And when thou hast fulfilled the orders of Thy God, who called thee to the field of battle, Then shalt thou lay the weapons far from thee, And turn once more unto the gentler sex, Which thou hast disavowed, for it is not Called on to do the bloody work of arms.

\section{JOHANNA}

Oh, reverend Sir, I know not yet to say

Just what the Spirit will command me do.

2215

But when the time has come, his voice will not

Be silent, and to it shall I give heed.

But now he bids me to complete my work.

My master's brow has still not yet been crowned.

The holy oil has not yet wet his head.

My master still is not addressed as king. 


\section{Charles}

We are advancing on the way to Rheims. JOHANNA

Let's not stand still, for busily engaged Are foes around about to close thy way. But I shall lead thee through their very midst!

\section{DUNOIS}

But when it all has been consummated, When we have marched as victors into Rheims, Wilt thou then grant to me, oh holy Maiden-

\section{JOHANNA}

If Heaven wills that I, with victory crowned, Return again from out this deadly battle, 2230

Then is my task fulfilled-the shepherdess Has no more business in her sovereign's house.

CHARLES (taking her hand).

The Spirit's voice is now impelling thee, And love is silent in thy God-filled bosom. It will not always be thus mute, believe me! Our weapons soon shall rest, for by the hand Doth victory lead peace; then joy returns Again to every breast, and tend'rer feelings Once more wake up in each and every heart. In thy breast too they surely will awaken, And tears of gentle longing wilt thou weep, Such as thine eyes have never shed-this heart, Which now is filled by Heaven alone, will then In love unto some earthly friend be wending. Now saving many thousand joyful men, By bringing joy to one thou shalt be ending!

$$
\text { JOHANNA }
$$

Dauphin! Art thou already weary of

The heavenly vision, that thou would'st destroy

Its form; the pure virgin sent by God, Wilt thou drag down into the common dust?

Ye blinded hearts! Oh, ye of little faith!

The majesty of Heaven gleams about you;

Before your eyes unveils its miracles, And ye behold in me naught but a woman.

Dare woman clothe herself in martial metal, And mix herself amid the strife of men? 
Woe's me, if I the 'venging sword of God

Bore in my hands, and in my selfish heart

Did bear a longing for an earthly man!

For me 'twere better I had ne'er been born!

2260

No more such words, I say to you, unless

You wish to rouse to wrath the spirit in me!

The eye of men that yearns but to possess me,

To me is horror and a desecration.

\section{CHARLES}

Desist! It is but vain to try to move her.

2265

$$
\text { JOHANNA }
$$

Command the warlike trumpets to be blown!

I'm burdened and annoyed when arms stand still,

I am impelled to leave this leisure state,

And driven on my mission to fulfill,

And urged despotically to meet my fate.

FIFTH SCENE

A Knight in haste.

What is't?

Charles

KNIGHT

The enemy has crossed the Marne

And settles down for battle.

$$
\text { JOHANNA (enthused). }
$$

Fight and battle!

Now is my soul delivered from its bonds.

Gird on your arms, while I array the forces.

(She hastens out.)

\section{ChARLES}

With her, La Hire! E'en at the gates of Rheims

They wish to make us struggle for the crown!

DunoIs

Real courage does not drive them. This last try

Is merely feebly raging desperation.

$$
\text { CHARLES }
$$

I goad you not, Burgundy. But today's

The day to mend for many evil days.

You shall be satisfied with me!

\section{BURGUNDY}




\section{ChaRLes}

I'll go before you on the road to fame.

\section{Myself,}

And in the face of the cor'nation-city

Will win the crown in battle. Now, my Agnes,

Thy knight bids thee farewell!

AGNES (embraces him).

For thee, I do not weep, I do not tremble;

My faith extends with trust into the clouds.

So many pledges of its favor Heaven

Hath not bestowed to make us end in sorrow!

With triumph crowned, in Rheims' surmounted walls,

2290 My heart tells me, I'll clasp my lord tomorrow.

(Trumpets resound with inspiring notes, and, while the scenery is being changed, they go over into a wild martial turmoil. The orchestra joins in when the scene opens and is accompanied by military instruments behind the scene.)

The scene changes into an open region, skirted by trees. While the music is playing one sees soldiers rapidly retreating across the background.

\section{SIXTH SCENE}

Talbot, supported by Fastolf and accompanied by soldiers. Immediately thereafter Lionel.

\section{TALBOT}

Here, underneath these trees, just set me down, And ye betake you back into the battle. I need not any aid that I might die.

\section{FASTOLF}

Oh, most unhappy, miserable day!

(Lionel enters)

To what a sight you come, oh Lionel!

Here lies the marshal wounded unto death!

\section{LIONEL}

That God forbid! Oh noble lord, arise! Now's not the time to sink to earth exhausted, Yield not to death, be master over nature 2300

With your all-potent will, and make her live! 
TALBOT

In vain! The day of destiny is come,

Which shall o'erturn our throne in French domains.

In vain in battle filled with desperation

I wagered my last mite to ward it off.

2305

Crashed now by lightning I am lying here,

No more to rise again.-And Rheims is lost.

So rush to rescue Paris!

\section{LIONEL}

Paris has made a treaty with the Dauphin.

A courier has just brought us the tidings.

2310

TALBOT (tears off his bandages)

Then flow away, ye brooklets of my blood,

For I am more than weary of the sun!

\section{LIONEL}

I cannot stay. You, Fastolf, bring our marshal

Into a safe location. Not much longer

Can we maintain ourselves in this position.

2315

Our troops already flee on every side,

Beyond restraint the Maiden presses on-

\section{TALBOT}

Thou, Folly, conquerest; I must succumb!

Against stupidity e'en gods contend in vain.

Exalted Reason, light-dispensing daughter

Of godlike brain, oh, wise establisher

Of this world's edifice, guide of the stars,

Who art thou then, if thou, bound to the tail

Of frenzy's insane steed, and calling out

In vain, must hurl thyself with open eyes

Into the abyss with thy maddened mount?

Accurs'd be he who turns his life to what

Is great and worthy, and draws up wise plans

With sapient spirit! To the king of fools

Belongs the world!

2320

2325

LIONEL

My lord, you have now, but

A few more moments left to live. -Oh think

Now of your Maker!

\section{TALBOT}

Were we as valiant men

O'ercome by other valiant men, we might 
Console ourselves with universal fate,

That spins the sphere in ever-changing manner-

But to succumb to such a hocus-pocus!

Was all our earnest and laborious life

Not worthy of a much more earnest exit?

LIONEL (extends his hand to him).

My lord, farewell! The wonted toll of tears

I'll pay you honestly, when strife has ceased,

If I am still around. However now

Fate calls me forth, who on the battlefield

Still sits there judging as it shakes the dice.

Until I see you in another world!

Short is this parting after lengthy friendship.

2345

(Exit.)

TALBOT

Soon it is over and I'll give to earth, To everlasting sun, its atoms back, Those which, for joy and sorrow, were joined in me.

And of the mighty Talbot, who has filled

The world with his own battle-fame, remains

2350

Naught but a handful of light dust. Thus goes

The mortal to his end. And the lone spoil,

Which from life's struggle we take off with us,

Is insight into nothingness, and too

A hearty scorn for everything that once

Appeared to us exalted and worth wanting.

\section{SEVENTH SCENE}

Charles. Burgundy. Dunois. Du Chatel and Soldiers enter.

\section{BURGUNDY}

The trench is taken by storm.

\section{DUNOIS}

The day is ours.

Charles (noticing Talbot).

See who it is, who yonder from the light

Of day is taking grave, reluctant leave.

His armor shows me he's no common man.

Go, rush to him, if aid avail him still.

(Soldiers from the King's retinue go to him.) 
FASTOLF

Stand back! Away! Have reverence 'fore the dead,

Whom ye in life have never dared approach!

BURGUNDY

What's this I see? In his own blood lies Talbot!

(He goes up to him. Talbot looks fixedly at him and dies.)

\section{FASTOLF}

Away, Burgundy! Let no sight of traitor

2365

Be poison to a hero's dying glance!

\section{DUNOIS}

The dreaded Talbot! The invincible!

Dost thou content thyself with such small space,

And France's wide terrain could not suffice

The striving of thy once gigantic spirit.

2370

-It's only now I greet thee, Sire, as king.

The crown sat trembling on thy royal head,

As long as in this body dwelt a spirit.

\section{CHARLES}

(after he has regarded the corpse in silence)

A Higher Being has vanquished him, not we!

He lies on France's soil as lies a hero

Upon his shield, which he would not abandon.

Bear him away!

(Soldiers lift up the corpse and carry it away.)

And peace be to his ashes!

A monument shall rise to do him honor.

Here in the midst of France, where his career

As hero had its end, his bones shall rest!

2380

As far as he no hostile sword hath thrust.

The place where he is found shall be his epitaph.

FASTOLF (surrenders his sword).

Sir, I am now thy prisoner!

CHARLES (returns his sword to him).

Not so!

Rude war doth likewise honor pious duty.

Free shall ye follow to your master's grave.

2385

Now hasten, Du Chatel! My Agnes trembles.

Release her from anxiety for us.

Bring her the message that we live, we conquered. 
In triumph lead her on to Rheims! (Du Chatel exit.)

\section{EIGHTH SCENE}

La Hire, joins the others.

Dunors

La Hire,

Where is the Maiden?

\section{LA HIRE}

What? I'll ask you that.

I left her fighting at your very side.

\section{DuNOIS}

I thought she was protected by your arm,

When I rushed off to speed the king my aid.

\section{BURGUNDY}

Amid the thickest hostile hordes I saw,

Not long ago, her snow-white banner waving.

2395

$$
\text { DunoIs }
$$

Woe's us! Where is she? Evil me forebodes!

Come, let's make haste to set her free!-I fear

Her daring nature's carried her toc far,

Encircled by the foe she fights alone,

And, helpless, she succumbs now to the horde.

Quick, rescue her!

\section{Charles}

\section{LA HIRE}

I follow! Come!

\section{BURGUNDY}

(They hasten forth.)

We all!

Another desolate region of the battlefield. The towers of Rheims are visible in the distance, illuminated by the sun.

\section{NINTH SCENE}

A Knight in black armor with closed visor.

Johanna pursues him even to the forward part of the stage, where he stands still and awaits her.

\section{JOHANNA}

Thou crafty one! I'm conscious of thy cunning!

Thou hast, deceiving, through pretended flight, 
Allured me from the field, and death and doom

From many heads of British sons averted.

But now perdition has caught up with thee.

BLACK KNIGHT

Why dost thou thus pursue me and cling fast

In ardent rage close to my heels? It's not

My destiny to perish at thy hand.

JOHANNA

Thou art abhorred by me with all my soul,

Just like the night, whose color is thine own.

To extirpate thee from the light of day

Invincible desire drives me on.

Who art thou? Ope thy visor! Had I not

Beheld the warlike Talbot fall in battle,

Then would I say, forsooth, that thou wert Talbot.

\section{BLACK KNIGHT}

Is thy prophetic spirit's voice now silent?

\section{JOHANNA}

It speaks aloud within my inmost breast,

That at my side misfortune now is standing.

BLACK KNIGHT

Johanna D'Arc! Up to the gates of Rheims

Thou hast pushed forward on the wings of triumph.

Suffice thee now the fame that's won. Set free

Good fortune, that has served thee as a slave,

Ere it in anger frees itself. It hates

Fidelity and till the end serves none.

2425

JOHANNA

What biddest thou, that I, in mid-career

Should now stand still and all my work forsake?

I'll see it through and thus redeem my vow!

BLACK KNIGHT

Naught can withstand thee, oh, thou Mighty One.

In every fight thou conquerest. But, go

2430

Into no battle more! Now heed my warning!

JOHANNA

This sword I shall not lay from out my hand

Till when proud England shall succumb in battle.

BLACK KNIGHT

Look there! There Rheims arises with its towers, 
The goal and end of thy career. The dome

Of its august cathedral see'st thou shining.

There shalt thou enter in triumphal splendor,

Shalt crown thy king and thus fulfill thy promise.

But go not in! Turn back! Oh heed my warning!

\section{JOHANNA}

Who art thou double-tongued, deceitful being,

Who seeks to frighten and confuse me too?

How darest thou, deceitful, to announce

False oracles to me?

(The Black Knight wishes to leave. She steps into his path.)

Reply to me, or die'st by my hand!

Oh, no! Thou givest

(She wishes to deliver a blow at him.)

BLACK KNIGHT

(touches her with his hand. She remains standing motionless).

Kill what is mortal!

(Night, lightning and thunder-clap. The Knight

sinks into the earth.)

JOHANNA

(Stands at first astonished, but soon recovers her composure.)

'Twas nothing living! 'Twas a phantom form

From out of hell, an insubordinate spirit,

Who climbed up here from out the fiery pool

To shock my noble heart within my bosom.

Whom do I fear with God's sword in my hand?

In triumph I shall consummate my way,

If hell itself into the lists came sneaking,

My courage shall not waver, shall not weaken!

(She wishes to leave.)

\section{TENTH SCENE}

Lionel. Johanna.

LIONEL

Accurséd woman, arm thee for a fight!

Not both of us shall leave this place alive.

The best among my people thou hast slain;

The noble Talbot hath his mighty soul 
Breathed out into my bosom. I'll avenge That valiant man, or I shall share his fate. And that thou knowest who lends thee thy fame, 2460 Though he should die or conquer-I'm Lionel, 'The last one of the princes of our host, And still unconquered is this arm of mine.

(He presses in on her. After a short duel she strikes the sword from his hand.)

Disloyal fortune! (He struggles with her.)

\section{JOHANNA}

(seizes him from behind by the plume of his helmet and tears the helmet down violently so that his visage is laid bare. At the same time she draws her sword with her right hand.)

Suffer what thou sought'st!

Through me thou art the Holy Virgin's victim.

(At this moment she looks him in the face. His aspect seizes her. She remains standing motionless and then lets her arm sink slowly.)

LIONEL

Why tarry and restrain the stroke of death? Take now my life as thou hast ta'en my fame, I'm in thy hands; I do not wish for mercy.

(She gives him a sign with her hand that he should depart.)

Shall I now flee? And owe thee thanks that I'm Alive?-I'd sooner die!

JOHANNA (with averted face).

Preserve thyself!

I will know naught thereof, that once thy life

Into my power was given.

LIONEL

I hate thee and thy gift; I do not wish

For mercy. Kill thy foe, who but abhors thee.

And who was willed to kill thee!

JOHANNA

-And flee!

Kill me then,

LIONEL

Ha! What is that? 
JOHANNA (conceals her face).

$\mathrm{Oh}$, woe is me!

LIONEL (comes nearer to her).

Thou killest, I am told, all Englishmen, Whom thou subduest in battle. Why spare me Alone?

\section{JOHANNA}

(raises her sword with a quick motion over him, but lets it sink quickly again when she looks him in the face.)

$$
\text { Oh, holy Virgin! }
$$

\section{LIONEL}

Why namest thou

The holy one? She knoweth naught of thee;

And Heaven hath no part in thee.

$$
\begin{gathered}
\text { JoHANNA (in violent anxiety). } \\
\text { What have }
\end{gathered}
$$

I done? My sacred vow, alas; I've broken!

(She wrings her hands despairingly.)

\section{LIONEL}

(observes her sympathetically and comes nearer to her.)

Unhappy maiden! Now I pity thee;

Thou movest me, to me alone thou hast

Been generous. I feel that now my hate

Doth disappear. I must now take thy part!

Who art thou? Whence art come?

$$
\begin{aligned}
& \text { JOHANNA } \\
& \text { Away! Take flight! } \\
& \text { LIONEL }
\end{aligned}
$$

Thy youth, thy beauty cause me to lament!

Thy look intrudes into my heart. I'd like

To rescue thee-but tell me how I can?

Come! Come! Renounce this terrible connection!

And cast away from thee these warlike weapons!

To bear them I'm unworthy!

$$
\text { JOHANNA }
$$

\section{LIONEL}

Away and follow me!

Throw them, quick, 


\section{JoHANNA (with dismay). And follow thee! \\ LIONEL}

Thou canst indeed be rescued. Follow me!

I'll rescue thee, but now do not delay!

A mighty pain takes hold of me for thee

And an untold desire to rescue thee.

(He takes hold of her arm.)

\section{JOHANNA}

The Bastard comes! 'Tis they! They're seeking me!

If they find thee-

\section{LIONEL}

I'll give thee my protection! 2500 JoHANNA

I'll die if thou shouldst fall before their arms.

Am I then dear to thee?

\section{LIONEL}

\section{JOHANNA}

Ye saints in Heaven!

$$
\text { LIONEL }
$$

Shall I see thee again? Or hear from thee?

No! Never!

$$
\text { JOHANNA }
$$

\section{LIONEL}

This thy sword as pledge that I

See thee again!

(He snatches her sword from her.)

JOHANNA

Demented man, thou darest it?

\section{LIONEL}

Now I shall yield to force. Again I'll see thee.

$$
\text { (Exit) }
$$

\section{ELEVENTH SCENE}

Dunois and La Hire. Johanna.

She lives! 'Tis she!

\section{LA HIRE}

\section{DUNOIS}

$$
\text { Johanna, have no fear! }
$$

Thy friends are standing at thy side in force. 


\section{LA HIRE}

Is't Lionel who flees?

\section{DUNOIS}

Just let him flee!

The righteous cause, Johanna, is the victor!

Rheims opens wide its gates, and all the folk

Pour cheering forth to go to meet their king-

LA HIRE

What ails the Maiden! She grows pale, she sinks!

(Johanna becomes dizzy and is about to collapse.)

DUNOIS

She has been wounded-tear her armor off!

It is her arm, and slight her injury.

Her blood flows forth!

\section{LA HIRE}

JOHANNA

Oh let it with my life

Stream out!

(She lies in a faint in La Hire's arms.)

\section{FOURTH ACT}

A hall adorned as for a festival. The columns are entwined with festoons, behind the scene music of flutes and oboes.

\section{FIRST SCENE \\ JOHANNA}

The weapons rest, the storms of war are stilled,

On bloody battles follow song and dance,

With cheery roundelay all streets are filled,

Both church and altar festal lights illume,

While verdant branches triumph-arches build, Around the columns winding wreaths advance;

Wide Rheims holds not the hosts of guests, who teeming,

Like pilgrims to the people's feast are streaming.

The rapture of one joy is now inflamed,

One thought alone now throbs in every breast;

What recently war's bloody hate had twained,

That shares once more, enthralled, the common zest.

He only who his Frankish birth proclaimed,

Is proudly conscious now when so addressed. 
Renewed is now the splendor of the throne, And France adores its king's son as her own.

But me, who all this glory has performed, Me touches not the general lot so gay; 2535

In me my heart's diverted and transformed, And from these festal rites it flees away.

Into the British camp it now has stormed.

Far over to the foe my glances stray,

From friendship-circles I must need be stealing,

2540

The grievous guilt within my heart concealing.

Who? I? The image of a man

In my pure bosom deign to carry?

This heart, which Heaven's glow o'erran,

Dare it an earthly love now harry?

2545

I, my fatherland's deliveress,

The highest God's protectoress,

For my own country's foe inflamed?

May that to the chaste sun be named,

And I not be destroyed by shame?

2550

(The music behind the scene goes into a soft languishing melody.)

Woe! Oh, woe's me! What sweet strains!

How they lead astray my ear!

Each recalls his voice again,

Conjures up his form right here!

Would the storm of battle seized me,

2555

Sighing spears around me sang

In the fervid battle's roar!

I would find my strength once more!

$\mathrm{Ah}$, these voices, ah, these accents,

How they wind around my heart!

2560

Every force within my bosom

They dissolve in tender yearning,

Melt to tears with sadness burning!

(After a pause, more vivaciously.)

Should I kill him? Could I, since I've looked

Into his eyes? Kill him? I'd sooner have

2565

The murd'rous steel plunged into mine own breast!

And am I culpable 'cause I was human? 
Is pity sinful? Pity! Didst thou hear

The voice of pity or humanity

When others too were victims of thy sword?

2570

Why was it mum-the while the youth from Wales,

The tender youth, was pleading for his life?

Oh, cunning heart, who light of truth forgot,

The pious voice of pity led thee not!

Why was I forced to look him in the eye!

2575

Behold the noble features of his face!

'Twas with thy gaze the trespassing began,

Unhappy maid! A sightless tool thy God demands;

With sightless eyes thou had'st the goal attained.

But once thou saw'st, forsaken by God's shield,

2580

Thou wert in snares of hell enchained!

(The flutes are heard again. She sinks into silent melancholy.)

Pious staff! Oh had I never

Thee for battle-sword exchanged!

Had a murmur in thy branches,

Holy oak, me ne'er estranged!

2585

Wert thou, Queen of Heaven, never

From on high revealed to me!

Take, I can't deserve it ever,

Take thy crown! I give it thee!

Oh, I saw the Heavens open

And the Virgin's sainted face!

But on earth is all my hoping,

And in Heaven is not my place.

Must thou this upon me burden,

This formidable vocation?

2595

Could I cause this heart to harden

2590

To which Heaven gave sensation?

Wilt thou have thy might proclaimed,

Choose but those by sin unblamed,

Standing in thy long-lived home.

2600

Thine own spirits send to roam,

Those most pure, those undying,

Those who know not feeling, crying!

Do not choose the tender maiden,

Shepherdess with soft heart laden! 
Should I reck the lot of battles, Or the sovereigns in their fights?

Guiltless once I drove my lambkins

On the quiet mountain heights.

Thou hast thrust me into living

In the haughty princes' hall,

Thus to guilt my being giving.

Oh 'twas not my choice at all!

\title{
SECOND SCENE
}

Agnes Sorel. Johanna.

\begin{abstract}
SOREL
(enters in vivid emotion; when she catches sight of the Maiden she hastens to her and falls upon her neck; suddenly, realizing the situation, she releases Johanna and prostrates herself before her.)
\end{abstract}

No! Not thus! Here in dust 'fore thee-

JOHANNA (wishes to raise her upi).

Arise!

What ails thee? Thou forgettest thee and me.

\section{SOREL}

Let me! It is the urge of joy that casts

Me down before thy feet; I must pour forth

My overflowing heart before my God,

The One Unseen I worship now in thee.

Thou art the angel who hath led my lord

To Rheims, and there adorn'st him with the crown.

What I had never dreamed I'd see is now

Fulfilled! The coronation train makes ready.

The King stands there in festal pomp arrayed.

Assembled are the peers, the mighty of

The realm, to bear the ornaments of office.

Cathedralwards the folk like pilgrims stream.

The dance-tunes sound e'en as the church bells peal.

The fullness of this joy I cannot bear!

(Johanna raises her gently to her feet. Sorel is silent for a moment, while she looks the Maiden more closely in the eye.)

But thou remainest ever grave and stern.

Good luck thou canst create but share'st it not. 
Thy heart is cold, thou feelest not our joys. Thou hast beheld the majesty of Heaven, No earthly fortune moves the pure breast.

(Johanna grasps her hand violently, but quickly releases it again.)

Oh could'st thou be a woman and have feeling!

2635

Lay off this armament, there's no war more,

Confess thou art one of the gentler sex!

My loving heart draws shyly back from thee

As long as thou art like the rigid Pallas.

What dost thou ask of me!

$$
\text { JOHANNA }
$$

SOREL

Disarm thyself.

Lay off this armament! For love doth fear To draw too near unto this steel-clad breast.

Oh, be a woman, then thou shalt feel love!

\section{JOHANNA}

Shall I disarm me now? Just now? To death

I will lay bare my breast in battle!

Not now - oh would that seven folds of bronze.

Protect me from your feasts and from myself!

SOREL

Count Dunois's love is thine. His noble heart,

To fame alone and hero's virtues open,

It glows for thee in holy tenderness.

2650

$\mathrm{Oh}$ it is fine to see one's self belov'd thus by

A hero,-but 'tis finer still to love him!

(Johanna turns away in abhorrence.)

Thou hatest him!--No, no, thou only canst

Not love him, but how couldst thou really hate him?

One hates but him who steals from us the one

2655

Beloved, but no one is by thee beloved!

Thy heart is calm-if only it could feel-

$$
\text { JOHANNA }
$$

Oh mourn for me! And weep anent my fate!

\section{SOREL}

Oh, what could still be lacking to thy fortune?

Thou hast redeemed thy word, and France is free;

Into the coronation city thou

Hast led the king in triumph and attained 
Exalted fame. A happy people praise

And worship thee, thy laud from every tongue

Doth overflow. Thou art the goddess of

2665

This feast. The crownéd king himself gleams not

More lordly than thyself.

JOHANNA

Conceal myself in earth's profoundest bowels!

Oh, could I but

SOREL

What ails thee? What a strange emotion this!

Who dare to look out freely on this day, 2670

If thou shouldst earthwards cast thy glances down?

Let me blush red, me, who near thee must feel

So small, who cannot raise herself to match

Thy lofty height and thy heroic strength!

And shall I now confess to thee my one

2675

Great weakness? Not the fame of fatherland,

And not refurbished glory of its throne,

Not popular elation, joy in triumph

Engages this weak heart. There is but one

Who fills it to completion. It has room

2680

But for this one and solitary feeling:

$\mathrm{He}$ is the one adored, for him the people cheer, Him do they bless, for him they strew these blossoms.

And he is mine, yes, he is my belovéd.

\section{JOHANNA}

Oh, thou art fortunate! I call thee blessed!

Thou lovest where all love! Thou may'st disclose

Thine heart and speak aloud thy rapture, and

Display it frankly to the gaze of man!

This feast of empire is thy feast of love.

All peoples here, and they are infinite,

Who surge into these walls as 'twere a flood,

They share thy feeling, which they sanctify;

For thee they cheer, for thee they wind a wreath,

And thou art one with all the common rapture!

Thou lovest what brings joy to all; the sun,

Whate'er thou seest, is thy love's own glow!

SOREL (falling on her neck.)

Oh, thou delightest me! Dost understand me!

Yea, I misjudged thee; thou art judge of love, 
And what I feel thou dost express with force.

My heart is freed from all its fear and shyness,

2700

And wells with confidence to meet with thee-

JOHAN.NA

(tears herself violently from her arms.)

Forsake me! Turn from me! Do not pollute

Thyself with my pestiferous encounter!

Be happy! Go! Let me in deepest night

Conceal my horror, my disgrace and my

2705

Misfortune-

\section{SOREL}

Thou dismayest me, I do

Not comprehend thee. But I never have-

To me thy dark deep being was ever veiled.

Who might divine by what thy holy heart,

Thy pure soul's soft feeling is affrighted!

2710

\section{JOHANNA}

Thou art the holy one! Thou art the pure!

Saw'st thou my inmost soul, then, shuddering,

Would'st thou reject me, traitoress and foe!

\section{THIRD SCENE}

Dunois. Du Chatel and La Hire with Johanna's banner.

\section{DUNOIS}

'Tis thee we seek, Johanna. All is ready.

The king has sent us. He desires that thou

Before him shall thy holy banner carry.

Thou shalt attach thyself to ranks of princes,

And closest to him thou thyself shalt march;

For he denies it not, and all the world

Shall witness it, that he to thee alone

2720

Attributes all the honor of this day.

\section{LA HIRE}

Here is the banner. Take it, noble Maiden!

The princes wait, and all the people tarry.

$$
\text { JOHANNA }
$$

I march before him! I, this banner carry!

\section{DUNOIS}

Whom else doth it befit? What other hand

Is pure enough to bear this sacred emblem? 
Amid the conflict thou didst make it wave,

Now bear it to adorn the way of joy.

(La Hire wishes to hand her the banner; she draws away from it shuddering.)

$$
\text { JOHANNA }
$$

Away! Away!

\section{LA HIRE}

What ails thee? Thou afraid

Of thine own banner! Stand and look at it!

2730 (He unfurls the banner.)

It is the same that thou didst wave in triumph.

Depicted on it is the Queen of Heaven, Who hovers over the terrestrial sphere.

For thus the Holy Mother showed it thee.

$$
\text { JoHANNA (looking at it in dismay.) }
$$

It's she! Herself! Just as she looked to me.

See how she glares and how she knits her brow,

And peers with glowing rage through lowering lashes!

\section{SOREL}

Oh she's beside herself! Come to thyself!

Collect thyself! Thou seest naught that's real!

That is her earthly, simulated form,

Herself, she wanders 'mid the choirs of angels!

\section{JOHANNA}

Awesome One, com'st thou to judge thy creature?

Destroy and punish me, take e'en thy lightning

And let it fall upon my guilty head!

My bond I've broken, and I have profaned

2745

And desecrated thy most holy name!

\section{DuNors}

Woe's us! What's that? Oh what unholy words!

LA HIRE (astonished, to Du Chatel).

Do you this strange emotion comprehend?

\section{Du Chatel}

I see just what I see. 'Tis long that I Have feared it.

\section{DUNOIS}

What is that you say?

Du Chatel 
Not speak that which I think. Would God that it

Were over and the king already crowned!

\section{LA HIRE}

What? Has the terror which this banner shed

Reverted back to fall upon thyself?

Before this symbol let the Britons tremble,

To foes of France it is a thing of dread,

But to her loyal citizens it's gracious.

$$
\text { JOHANNA }
$$

Thou speakest right! To friends it is propitious, And to the foe it sendeth consternation.

(The coronation march is heard.)

\section{DUNOIS}

So take the banner! Take it! They begin

The march, and not one moment may we tarry!

(They force the banner upon her. She seizes it after

violent resistance and departs. The others follow her.)

The scene changes to an open place in front of the cathedral.

\section{FOURTH SCENE}

Spectators fill the background; from among them come Bertrand, Claude Marie and Etienne. They come forward, following them Margot and Louison. The coronation march resounds muffied from the distance.

\section{BERTRAND}

The music! Hark! 'Tis they! They're drawing near!

What's best to do? Shall we ascend the platform

Or press our way on through the crowd of people,

In order to miss none of the procession?

ETIENNE

There is no getting through, for all the streets

Are thronged with people, mounted and in coaches.

Let's move up close toward these houses here.

Here we can see the march, and be in comfort

When it is passing by.

Claude Marie

It is as if

One half of France were gathered here together!

So overwhelming is the flood that it

Us too, from our far distant land, Lorraine,

Has lifted up and washed to here! 


\section{BERTRAND}

\section{Who will}

Sit idly in his corner when within

2775

The fatherland a great event transpires!

And it has cost us blood and sweat enough

Before the crown came to the proper head!

And our king, who is the king in truth,

On whom we now bestow the crown, shall have

2780

No meaner escort than the Parisians' king,

Whom they at Saint Denis did crown. That is

No well-intentioned man, who from this feast

Abstains, nor joins our cry: "Long live the king!"

\section{FIFTH SCENE}

Margot and Louison join them.

\section{LOUISON}

We shall again behold our sister, Margot!

2785

My heart exults.

\section{MARGOT}

In pomp and majesty

We shall behold her and shall tell ourselves:

It is Johanna, it is our sister!

\section{LOUISON}

I can't believe it, till with mine own eyes

I've seen that this so mighty maid they call

The Maid of Orleans really is our sister, Johanna, who by us was counted lost!

(The march continues to come nearer.)

MARGOT

Thou doubtest still? Thine eyes shall yet behold it!

BERTRAND

Give heed! They come!

\section{SIXTH SCENE}

Flute-players and oboists open the procession. Children dressed in white and with branches in their hands follow. Behind these two heralds. Then a rank of halberdiers. Magistrates in robes follow. Then two Marshals with their staffs. The Duke of Burgundy carrying the sword, Dunois with the sceptre, other dignitaries with the crown, the imperial globe and the staff of 
justice; others with sacrificial offerings; behind these Knights with decorations signifying their order. Choir-boys with the censor; then two Bishops with the cruet of holy chrism. The Archbishop with the crucifix. Johanna with her banner follows him. She walks with bowed head and uncertain step; her sisters, upon beholding her, give signs of astonishment and joy. Behind her comes the King under a baldachin carried by four barons; courtiers follow, soldiers close the procession. When the procession has entered the church, the music of the march ceases.

\section{SEVENTH SCENE}

Louison. Margot. Claude Marie. Etienne. Bertrand.

Didst thou see sister?

\section{MARGOT}

\section{Claude Marie}

She, in golden armor,

Who marched before the king and bore the banner!

\section{MARGOT}

'Twas she. It was Johanna, our sister!

\section{Louison}

She recognized us not! She did not feel The nearness of the bosoms of her sisters.

She looked to earth and seemed to be so pale, And walked with trembling gait beneath her banner-

When I beheld her, I could not rejoice.

\section{MARGOT}

So, now arrayed in pomp and majesty I have beheld our sister. But who would Have thought, or e'en in dream suspicioned, When she was herding sheep out in our mountains, That we should e'er behold her in such splendor?

\section{Louison}

Our father's dream has been fulfilled, that we At Rheims before our sister would kneel down. That is the church that father in his dreams Beheld, and now is everything fulfilled. But father saw to boot sad stories too. Oh, I'm distressed to see her thus so grand! 
BERTRAND

Why stand we idly here? Come in the church

To watch the holy office!

2815

MARGOT

Yes, come on!

Mayhap that we shall meet our sister there.

\section{Louison}

We have already seen her. Let's return

Into our native village!

\section{MARGOT}

What? Before

We've greeted and addressed her?

\section{LOUISON}

To us no more; her place is with the kings She belongs

And princes. Who are we that we should thrust

Ourselves with idle pride into her splendor?

To us she was a stranger when still ours!

\section{MARGoT}

Will she be 'shamed of us and even scorn us?

\section{BERTRAND}

The king himself is not ashamed of us.

He greeted friendly e'en the humblest folk.

Be she extolled, however high she may, The king is even greater!

(Trumpets and kettle-drums resound from the church.)

\section{Claude Marie}

Come! To church!

(They hasten into the background and lose themselves in the crowd.)

\section{EIGHTH SCENE}

Thibaut enters dressed in black. Raimond follows him and wishes to restrain him.

\section{RAIMOND}

Stay, father Thibaut! Stay without the throng!

Here you behold but joyous-minded men,

Your grimness is offensive to this feast.

Come, let us flee the town with hasty paces. 


\section{Thibaut}

Didst thou behold my most unhappy child?

Didst thou observe her well?

\section{RAIMOND \\ I beg thee, flee! \\ THIBAUT}

Didst thou remark how all her footsteps faltered, How pale and how distraught her visage was?

The most unhappy girl feels her condition;

Now is the nick of time to save my child,

And I will use it.

(He wants to leave.)

\section{RAIMOND}

Wait! What will you do?

\section{THIBAUT}

I will surprise her, I will plunge her down

Out of her idle fortune; yea, with force

I'll lead her back unto her God, whom she

Renounced.

\section{RAIMOND}

Alas, oh weigh your actions well!

Plunge not your own dear child into perdition!

THIBAUT

If but her soul survive, her frame may perish!

(Johanna rushes out of the church without her banner. The crowd rushes up, adores her, and kisses her garments. She is detained in the background by the crowd.)

She comes!' Tis she! She rushes pale from church;

Her anguish drives her from the sanctuary.

The judgment of the heavenly tribunal

Reveals itself in her.

\section{RAIMOND}

So then farewell!

Require not that I attend you further!

I came all hope, and now I leave all sorrow.

I have beheld your daughter once again

And feel that I have lost her now anew.

(He departs. Thibaut departs on the opposite side.) 


\section{NINTH SCENE}

Johanna. The Populace. Later, her sisters.

\section{JOHANNA}

(has warded off the crowd and comes forward.)

I can't remain - the spirits here pursue me,

The organ's tones resound to me like thunder,

2855

Cathedral arches plunging fall upon me.

The free expanse of heaven I must seek me!

I left my banner in the sanctuary.

My hand shall touch it never, nevermore!

To me it seemed as if I'd seen my sisters,

Dear Margot and Louison, as in dream

Go gliding past in front of me. Alas!

It was a mere deceptive apparition!

They're far, so far and distant from my reach,

As happiness of childhood innocence!

2865

'Tis she! It is Johanna!

$$
\text { MARGOT (coming forward). }
$$

LoUISON (hastening toward her).

Oh, my sister!

\section{JOHANNA}

It was no dream-it's you-and I embrace you,

It's thou, my Margot, thou, my Louison!

Here in the foreign, richly-peopled desert

My arms enfold my pious sisters' breast.

MARGOT

She knows us still, is still the good, dear sister.

JOHANNA

And still your love doth lead you here to me,

So far, so far! You're not enraged at me,

Who left you without love and without leave!

\section{LOUISON}

God's mystical decree led thee away.

\section{MARGOT}

The fame of thee, which moves the whole, wide world, Which makes thy name to be on every tongue,

Has waked us in our quiet, little village,

And led us to this feast's festivity.

We come to witness thy magnificence, 
JOHANNA (quickly).

And father's with you too?

Oh, where is he? Why does he hide himself?

MARGOT

No, father's not with us.

$$
\text { JOHANNA }
$$

He's not? He does not wish

To see his child? You bring me not his blessing?

\section{LOUISON}

He knows not that we're here.

\section{JOHANNA}

He knows it not?

And then why not? You are confused? You're mute And look to earth! Come tell me: Where is father?

\section{MARGOT}

Since thou art gone-

$$
\begin{gathered}
\text { LOUISON (makes a sign to her). } \\
\text { Oh, Margot! } \\
\text { MARGOT }
\end{gathered}
$$

Become depressed in soul.

$$
\text { Father has }
$$

\section{JOHANNA}

Depressed!

\section{LOUISON}

Take heart!

Thou knowest father's e'er-foreseeing soul!

He'll be composed and put himself at peace,

When we relate to him that thou art happy.

\section{MARGOT}

But art thou happy? Yea, thou must be so,

Since thou art great and honored!

\section{JOHANNA}

Since I see you again and recognize Yes, I am,

Your voices' well-loved tone that now recalls

To me the fields of our paternal home.

There, where I drove the herds upon our highlands, There was I happy as in Paradise-

Can I not once again be or become so? 
(She hides her face on Louison's breast. Claude Marie, Etienne, and Bertrand appear and remain shyly standing at a distance.)

\section{MARGOT}

Come, Etienne! Bertrand! and Claude Marie!

Our sister is not proud, she is so tender.

And speaks so friendly, as she ne'er hath done

When she still lived with us in our small village.

(Those addressed approach and offer her their hand. Johanna

looks at them with a fixed stare and falls into deep amazement.)

\section{JOHANNA}

Where was I? Tell me! Was it, all of it, 2905

But a long dream, and am I now awake?

Am I away from Dom Remi? Is't true?

I fell asleep beneath the magic tree,

Am now awake and you stand 'round about me,

You well-beknown and long familiar figures?

2910

And this, about these kings and fights and deeds

Of war, these I have merely dreamed-They've been

But shadows, which went drifting on before me;

For underneath this tree one's dreams are vivid.

How came you here to Rheims? How came I here

2915

Myself? I ne'er forsook our Dom Remi!

Confess it frankly and make glad my heart.

\section{LOUISON}

We are in Rheims. And of these dreams thou hast

Not merely dreamed, thou hast achieved them all

In fact. Look 'round thee and know what thou art!

Just feel thy gleaming, golden, martial armor!

(Johanna passes her hand over her breast, reflects and is startled.)

\section{BERTRAND}

'Twas from my hand that you received this helm.

ClaUde MARIE

It is no wonder that you think you dream;

For what you have accomplished and performed

Can happen no more wondrous in a dream.

JoHANNA (quickly).

Come let us flee; I'll go with you, return

Into our village, to our father's bosom. 


\section{LOUISON}

Oh come, come with us!

JOHANNA

All these people here

Extol me far above my own deserts.

But you have seen me childish, small and weak.

2930

You love me, but you do not worship me!

MARGOT

Thou would'st abandon all this pomp and splendor?

JOHANNA

I cast it from me, this detested show,

Which separates this heart of mine from yours.

I will become again a shepherd girl.

2935

And as a lowly maiden I will serve you, And I'll repent, with all the strictest penance

For having vainly raised myself above you.

(Trumpets sound.)

\section{TENTH SCENE}

The King comes from the church; he is in his coronation regalia. Agnes Sorel, The Archbishop, Burgundy, Dunois, La Hire, Du Chatel, Knights, Courtiers and the Populace.

\section{ALL VoICES}

(shout repeatedly while the King advances).

Long live the King, long live our Charles the Seventh!

(The trumpets join in. On a sign given by the King, the Heralds command silence.)

\section{KING}

My good, kind folk! Have thanks for all your love!

2940

The crown, which God upon our head has set,

Was won by us and conquered by the sword.

With noble blood of commoners it's wet,

But peaceful shall the olive branch entwine it.

Thanks be to all of you who fought for us.

2945

And all, who stood against us, be forgiven,

For God has shown His mercy unto us

And our first word as king be also-Mercy!

Populace

Long live the King! Long live King Charles, the Good! 
KING

From God alone, the highest ruling being, 2950

The kings of France receive their royal crown.

But we in manner visible to sight

Received it from his hand.

(Turning to the Maiden.)

Here stands the woman, sent by God, who gave

You once again your own ancestral king,

2955

And broke the yoke of foreign tyranny!

Her name shall equal that of Saint Denis,

Who is the famed protector of this land,

And to her fame an altar shall arise!

\section{POPULACE}

Hail, hail, the Maiden, our Deliverer!

(Trumpets.)

KING (to Johanna).

2960

If thou art born of human flesh as we,

Then tell us what good fortune can delight thee;

But if thy fatherland is up above,

If thou concealest in thy virgin form

The radiance of high celestial nature,

Then take the blinding fold from off our senses,

And let us see thee by the light transfigured,

As Heaven sees thee, that, in adoration,

We groveling honor thee.

(A general silence. Every eye is directed toward the Maiden.)

JoHANNA (suddenly cries out).

Oh God! My father!

\section{ELEVENTH SCENE}

Thibaut steps forth from the crowd and stands face to face with her.

Her father!

$$
\text { SEVERAL VoICES }
$$

THIBAUT

Yes, her miserable father,

Who did beget this luckless girl, and whom

God's judgment drives to plaint against his daughter.

Hah! What is that?

BURGUNDY 


\section{Du Chatel}

Now dawns a dreadful dawn!

\section{THIBAUT (to the king).}

Thou weenest thou wert saved through God's own might?

Deluded prince! Oh blinded Frankish people!

Thou hast been rescued through the devil's wiles.

(All draw back in astonishment.)

\section{DuNOIS}

This man doth rave?

\section{ThIBAUT}

Not I, but thou dost rave,

And these men here and this the learned bishop,

Who think the Lord of Heaven would indeed

Proclaim himself through such a wicked maiden.

2980

Let's see if she, right to her father's face,

Maintains this trickery of boldest lies

With which she has deceived her king and people.

Now answer me upon the Trinity:

Dost thou adhere to saints and purity?

(General silence; all eyes are fixed on her; she stands motionless.)

\section{SOREL}

Oh God, she's mum!

\section{THIBAUT}

She must be 'fore the dreadful name,

That in the very depths of hell

Is dreaded!-She a holy woman sent

By God? Upon a curséd place it was

Conceived, beneath the magic tree, where e'en

2990

In olden times the evil spirits held

Their Sabbath. Here unto the enemy

Of man she bartered her immortal soul,

That he with b'rief and earthly fame extol her.

Let her lay bare her arm, behold the points

Wherewith old hell has marked her for its own!

\section{BURGUNDY}

Revolting! But one must believe a father

Who witnesses against his very daughter.

\section{Dunors}

No, not this raving man should one believe, Who in his very child defames himself. 


\section{SOREL (to Johanna)}

Oh, speak! Oh break this unpropitious silence!

We credit thee! We firmly trust in thee!

One word from out thy mouth, one single word, Shall us suffice. But speak! And render naught

This horrid accusation. But declare

Thou art not guilty and we'll credit thee. (Johanna stands motionless; Agnes Sorel walks away from her in dismay.)

\section{LA HIRE}

She's terrified. Amazement and dismay

Close tight her mouth. In face of such severe

Indictment innocence itself must tremble. (He draws near to her.)

Compose thyself, Johanna! Be thyself!

The guiltless has a tongue, a victor's eye,

Which, with the might of lightning, strikes down slander.

In noble wrath arouse thyself, look up,

And scourge and put to shame ignoble doubt,

That villifies thy holy virtue!

(Johanna stands motionless. La Hire retreats affrighted. The commotion increases.)

\section{DuNoIs}

Why flinch the folk? Why tremble even princes?

She is not guilty! I will vouch for that.

I vouch for her with all my princely honor.

Here on the earth I cast my knightly gauntlet.

Who dares now to assert that she is guilty?

(A violent crash of thunder; all stand amazed.)

THIBAUT

Give answer by the God who o'er us thunders!

Say thou art innocent! Deny the foe

Is in thy heart and brand me as a liar!

(A second, more violent clap of thunder. The populace flees in all directions.)

\section{BURGUNDY}

Oh God protect us! What a dreadful token!

Du Chatel (to the King.)

Come, come, my King! Oh let us flee this place!

I ask thee in God's name: Art thou now silent 
Because thou feelest innocence or guilt? If now this voice of thunder speaks for thee So clasp this crucifix and give a token!

(Johanna remains motionless. New, violent thunderclaps. The King, Agnes Sorel, the Archbishop, Burgundy, La Hire and Du Chatel depart.)

\section{TWELFTH SCENE}

Dunois. Johanna.

DunoIs

Thou art my wife.-I have believed on thee 3030

From the first sight, and think the same e'en now.

In thee I trust more than in all these signs,

More than in thunder speaking from above.

In noble anger thou art mum, and scornest,

Enveloped in thy holy innocence,

To contradict such scandalous suspicion.

3035

Resent it, but repose thy trust in me!

I've never doubted on thine innocence.

Tell me no word, but give thine hand to me

As pledge and token that thou dost rely

In truth on my strong arm and thy good cause.

(He extends his hand to her. She turns away from

him with convulsive emotion. He remains standing in rigid horror.)

\section{THIRTEENTH SCENE}

Johanna. Du Chatel. Dunois. Finally Raimond.

DU CHATEL (returning).

Johanna D'Arc! The monarch will allow

That you may leave the city unmolested.

For you the gates stand open. Fear no harm,

No insult; for the monarch's peace protects you-

Count Dunois, follow me; you have no honor

To linger here.-Oh, what an ending!

(He leaves. Dunois recovers from his stupor with a start, casts one more glance at Johanna, and departs. She stands for a moment entirely alone. Finally, Raimond appears, remains standing for a while at a distance and regards her with silent pain. Then he walks up to her and clasps her by the hand.) 


\section{RAIMOND}

Oh seize the moment! Come! Oh come! The streets Are clear. Give me your hand. I'll lead you hence.

(At the sight of him she gives the first sign of emotion, looks at him fixedly and glances toward Heaven. Then she seizes him violently by the hand and departs.)

\section{FIFTH ACT}

A wild forest. In the distance charcoal-burners' huts. It is completely dark. Violent thunder and lightning, interspersed wiih shooting.

\section{FIRST SCENE \\ Charcoal-Burner and his Wife.}

\section{Charcoal-Burner}

That is a dreadful, murd'rous thunder-storm, The heaven threats to pour itself down on us In streams of fire, and e'en in brightest day It's night, that one might even see the stars. Just like all hell let loose the storm does rave, The earth does tremble, and the trees of ash, 3050 Grown old with years, bend down their cracking crowns. And this terrific war up there above, Which even teaches wild beasts to be docile, And makes them tamely hide them in their caves, Cannot establish peace among the humans. 3060 Above the howling of the winds and storms You hear the thunder of the cannons' roar; Both armies stand so near to one another, That but the forest parts them, and each hour It can erupt in bloody fearfulness. 3065

\section{ChARCOAL-BURNER'S WIFE}

Oh God assist us still! Our enemies Already were rebuffed and caused to flee. How comes it that they frighten us anew?

\section{CHARCOAL-BURNER}

That is because they fear the king no more.

E'er since the Maid became a witch at Rheims 3055 The wicked fiend no longer helps our cause And all goes backward. 


\section{SECOND SCENE}

Raimond and Johanna join the others.

\section{RAIMOND}

I here see cabins. Come, here we shall find A shelter from the raging storm. You can't Hold out much longer. Now three days already You've wandered, fleeing from the eyes of men, And rugged roots were all you've had to eat.

(The storm abates. It becomes bright and clear.)

They're kindly charcoal-burners. Let us enter.

CHARCOAL-BURNER

You seem to be in need of rest. Come in! Whate'er our humble roof affords is yours

\section{ChARCOAL-BURNer'S WIFE}

What wills this tender maiden with these weapons?

Of course the present is a grievous time, When e'en a woman clothes herself in armor!

The queen herself, Dame Isabeau, they say, Is seen in armor in the hostile camp, A maiden too, the offspring of a shepherd, Has for the king, our master, fought in battle.

\section{CHARCOAL-BURNER}

What's that you say? Go in the hut and bring A goblet of refreshment for the maiden! (The Charcoal-Burner's wife goes into the hut.)

\section{RAIMOND (to Johanna).}

You see all humans are not merciless,

And in the forest too dwell gentle hearts.

Now brighten up! The storm has spent its fury, And beaming peacefully the sun goes down.

Charcoal-Burner

I guess you wish to join our monarch's host, Since you are travelling armed. But be alert!

The Englishmen have set up camp near by, And troops of theirs are scouting through the woods.

\section{RAIMOND}

Woe's us! How can we then escape? 


\section{Charcoal-Burner}

Until my boy comes back from out the town.

\section{Remain}

On hidden footpaths he will lead you forth,

So that there's naught for you to fear. We know

The by-ways.

$$
\text { RAIMOND (to Johanna). }
$$

Lay the helm and armor off.

They mark you out and offer no protection.

(Johanna shakes her head.)

CharCOAL-BURNer

The maiden is quite sad.-But hark! Who comes?

\section{THIRD SCENE}

The Charcoal-Burner's Wife comes from the hut with a goblet. The Charcoal-Burner's Boy.

\section{CharCOAL-BurNer's WiFE}

It is the boy for whose return we waited.

3105

$$
\text { (To Johanna) }
$$

Drink, noble maiden! May God bless it you!

Charcoal-Burner (to his son).

Art come, Anet? What bring'st thou?

\section{CHARCOAL-BURNER'S BOY}

(Has fixed his gaze on the Maiden, who is just raising the goblet to her mouth. He recognizes her, walks up to her and snatches the goblet from her lips.)

\section{Mother! Mother!}

What art thou doing? Who's thy guest? That is the witch Of Orleans!

Charcoal-Burner and Charcoal-Burner's Wife Oh, God have mercy on us!

(They make the sign of the cross and flee)

\section{FOURTH SCENE}

Raimond. Johanna.

$$
\text { JoHANNA (composed and gently). }
$$

Thou seest, a curse pursues me and all else flees me;

Care for thyself and leave me to my fate. 
RAIMOND

I should desert you? Now? And who would be Your escort?

\section{JOHANNA}

I am not without an escort.

The thunder over me thou too hast heard.

My fate doth lead me. Worry not! I shall

3115

Attain my goal without my seeking it.

RAIMOND

Where will you go? Here stand the Englishmen,

Who grimly swore to you a bloody vengeance.

There stand our troops, who have rejected you, An exile-

JOHANNA

3120

Naught befalls me but what must be.

RAIMOND

Who shall seek out your food? And who protect you

From savage beasts and still more savage humans?

Who care for you, when you are sick and wretched?

JOHANNA

I know both all the herbs and all the roots.

'Twas from my sheep I learned how to distinguish

3125

The healthful from the poisonous ones. I know

The courses of the stars, the flight of clouds.

I hear the rushing of the hidden waters.

Man needs but little, and rich life abounds

In nature.

RAIMOND (clasps her by the hand).

Will you not survey your soul,

Be reconciled with God and turn repenting

Back into the bosom of the Holy Church?

$$
\text { JOHANNA }
$$

Thou too dost hold me guilty of grave $\sin$ ?

$$
\text { RAIMOND }
$$

Must I not? Through silence your confession-

$$
\text { JOHANNA }
$$

Thou, who hast followed me into my exile,

The only being who was staunch and true,

Who chained himself to me, when all the world

Rejected me, thou too regardest me

An outcast spurning God? 
(Raimond remains silent.)

$$
\text { RAIMOND (astonished) }
$$

You mean you really are no sorceress?

I, a sorceress?

\section{JOHANNA}

\section{RAIMOND}

These miracles?

You have accomplished them with power from God And all his saints?

\section{JOHANNA}

Then, with what power else?

\section{RAIMOND}

And you kept silent to the terrible

Indictment? Now you speak, but then before the KingWhen speaking had availed, you held your tongue!

\section{JOHANNA}

In silence I submitted to my fate

Which God, my Master, over me imposed.

\section{RAIMOND}

You could make no reply unto your father?

$$
\text { JOHANNA }
$$

Since it from father came, it came from God.

The proving, likewise, will be fatherly.

\section{RAIMOND}

The Heaven itself bore witness to your guilt!

The heavens spoke, hence I was mum.

$$
\text { JOHANNA }
$$

\section{RAIMOND}

You could

Have cleared yourself with but one word, and yet

You left the world in this unhappy error?

$$
\text { JOHANNA }
$$

It was no error, but a visitation.

\section{RAIMOND}

You suffered all this shame though innocent, And not one plaint was uttered by your lips! I am amazed at you and stand unstrung. My heart convulses in my deepest bosom! 
Oh, gladly I accept your word as truth, For it was hard for me to think you guilty. But could I dream that any human heart Would suffer such a monstrous charge in silence?

\section{JOHANNA}

Did I deserve to be his emissary

Unless I blindly did my Master's will?

And I am not so wretched as you think. I suffer want, but that is not misfortune For my estate. I'm fugitive and banned, But in the desert learned to know myself. 3170

There, where the gleam of honor, shone around me, There, was there strife within my heart; I was The most unfortunate maid when to the world I seemed most fit for envy.--Now, I now Am healed. This storm in nature, threatening it With dire destruction, was to me a friend. It purified the world, and, with it, me.

In me is peace-and, come whatever will, I am no longer conscious of a weakness.

RAIMOND

$\mathrm{Oh}$, come, come, let us hasten to reveal 3180

Loud, loudly to the world your innocence! JOHANNA

He, who has sent confusion, will dispel it! The fruit of fate falls only when it's ripe!

A day will come when I'll be purified. And those who now reject me and condemn me, They will be rendered conscious of their folly, And tears will flow for what has been my fate.

\section{RAIMOND}

I should endure in silence, till by chanceJOHANNA (gently taking him by the hand).

Thou seest but the natural course of things, Because an earthly band beshrouds thy gaze.

But with mine eyes I've seen the things undying.

Unless the Gods so will, no single hair

Shall fall from head of man.-Seest thou the sun

Descending in the heavens? Just as surely

As it returns in glory in the morning,

So surely will the day of truth be dawning! 


\section{FIFTH SCENE}

Queen Isabeau with soldiers appears in the background.

ISABEAU (still behind the scene.)

This is the way into the English camp!

RAIMOND

Woe's us! The enemy!

(Soldiers enter. As they approach they notice Johanna and reel back in terror.)

ISABEAU

What stops the march?

God be our aid!

\section{SOLDIERS}

\section{ISABEAU}

A ghost has frightened you?

Well, are you soldiers? Ninnies! That you are!

(She forces her way through them, comes forth, but startles when she beholds the Maiden.)

What do I see?

(She quickly gains control of herself and advances towards her.)

My prisoner!

Surrender! Thou art now

\section{JOHANNA}

I am.

(Raimond flees with signs of despair.)

ISABEAU (to the soldiers).

Put her in chains!

(The soldiers timidly approach the Maiden. She extends her arms and is fettered.)

Is that the mighty woman, the much-feared,

Who chased your hordes like flocks of little lambs,

Who now cannot protect her very self?

Does she work wonders only where there's faith,

And, when she meets a man, become a woman?

(To the Maiden.)

Why didst thou leave thy army? Where is now

Count Dunois, thy knight-errant and protector?

I'm banished.

JOHANNA 
ISABEAU

What? How's that? Thou sayest "banished"?

Art banished by the Dauphin?

\section{JOHANNA}

Ask me not!

I'm in thy power, so now decide my fate.

ISABEAU

Art banished 'cause thou saved him from the depths, And set the crown upon his brow at Rheims, And over all of France hast made him king?

Art banished! There I recognize my son!

-Lead her to camp and show unto our troops, This dreaded spook 'fore whom they all have trembled!

Is she a sorceress! Her only magic

Is your delusion and your coward hearts!

A fool she is, who sacrificed herself

To save her king and now for that receives

The king's reward.--Bring her to Lionel-

The fortune of the Franks I send him bound!

I'll follow fast.

\section{JOHANNA}

To Lionel? Oh slay

3225

Me here, before I'm sent to Lionel!

$$
\text { ISABEAU (to the soldiers). }
$$

Give heed to my commands! Away with her!

\section{SIXTH SCENE}

Johanna. Soldiers.

JoHANNA (to the soldiers).

Ye Englishmen! don't suffer that alive

I slip from out your hands. Avenge yourselves!

Draw forth your swords and plunge them in my heart,

3230

Drag me, unsouled, before your general's feet!

Think! It was I who killed your most distinguished,

Who never carried pity in my heart,

Who caused entire streams of English blood

To flow, and robbed your brave heroic sons

3235

Of the glad day of going home again!

Take now a bloody vengeance! Murder me! 
You have me now. Not always shall you thus Behold, me weakLEADER OF THE SOLDIERS

Do what the queen commanded! 3240

JOHANNA

Should I then

Become more wretched than I was before? Oh, awful saint, thy heavy hand smites sore! Hast thou cast me from favor once revealed? No god appears, nor comes e'en angel more. All wonders cease and Heaven's gates are sealed. (She follows the soldiers.)

3245

\section{THE FRENCH CAMP SEVENTH SCENE}

Dunois between the Archbishop and Du Chatel. ARCHBISHOP

Control your melancholy temper, Prince!

Come with us! Turn unto your king once more!

Do not desert our general, common cause Just in this moment when, hard pressed anew, We stand in need of your heroic arm.

\section{DUNOIS}

And why are we hard pressed? Why does the foe Rise up again? Already all was done.

France was triumphant and the war was ended. The saviour you have banished. Now, just save Yourselves! But I will never see

The camp again, when she's no longer there.

$$
\text { Du Chatel }
$$

Accept our better counsel, Prince. Dismiss

Us not with such an answer!

\section{DUNOIS}

Hush, Du Chatel!

I hate you and from you wish naught to hear.

'Twas you who first expressed your doubt in her.

\section{ARCHBISHOP}

Who did not wax uncertain and not waver In faith in her on that unhappy day, When all the signs bore witness dead against her? 
We were astonished and benumbed. The blow

Befell our hearts too shattering. Who could,

In that distressing hour, weigh and prove?

But now cool-headedness returns to us.

We see her as a wanderer in our midst,

And find in her not any fault at all.

We are confused; we fear we have committed

3270

A grave injustice-E'en the King repents.

The Duke now blames himself. La Hire despairs,

And every heart now veils itself in mourning.

DunOIS

She a deceiver? If e'er truth desires

Embodiment in form that's visible,

3275

Then it must wear her features as its own.

If purity of heart, faith, innocence,

Dwells anywhere on earth,-upon her lips,

Within her placid eyes, there it must dwell!

\section{ARCHBISHOP}

May Heaven through a miracle project

3280

Itself into our midst and clear this secret,

Which our own mortal eyes can't penetrate.

Howe'er it be unraveled and dissolved,

One of two faults we have been guilty of:

We have defended us with magic arms

Of hell, or else a saint of God we've banned!

And each calls down the Heaven's wrath and harms

Upon this most unhappy fatherland.

\section{EIGHTH SCENE}

A Nobleman joins the others, later Raimond.

\section{NOBLEMAN}

A youthful shepherd asks about thine Highness.

He urgently demands to speak with thee.

He comes, he says, sent by the Maiden-

\section{DuNOIS}

Bring him to us! He comes from her!

Hasten!

(Nobleman opens the door for Raimond. Dunois hastens toward him.)

Where is the Maiden?

Where's she? 


\section{RAIMOND}

Hail, my noble Prince!

And hail to me that I this pious bishop, The holy man, the shield of the oppressed, 3295

The father of the orphaned, find with you!

\section{DUNOIS}

Where is the Maiden?

\section{ARCHBISHOP}

Tell us where, my son!

\section{RAIMOND}

Sir, she is not a doer of black magic!

By God and all his saints I vouch for that.

The folk's in error. Innocence you've banished;

3300

A woman sent by God you have cast out!

Where is she? Speak!

\section{Dunors}

\section{RAIMOND}

I was her only comrade

Upon her flight into the Ardennes forest.

There she confessed her inmost thoughts to me.

In torture I will die, and may my soul

Of everlasting bliss enjoy no share,

If she's not pure, my lord, and free from guilt!

DUNOIS

The sun in heaven itself is not more pure!

Where is she? Speak!

\section{RAIMOND}

Alas, if God hath changed

Your heart-so hasten now and rescue her!

3310

She's now held captive by the Englishmen.

Held captive? What?

\section{DUNOIS}

\section{ARCHBISHOP}

Oh most unhappy maid!

RAIMOND

Out in the Ardennes, where we sought f $c$ r shelter, There she was taken hold of by the queen, And then delivered into English hands.

Oh rescue her, as she once rescued you, From a most fear-provoking death! 


\section{DUNOIS}

To arms! Arise, and give alarm! And roll your drums!

Lead all our people to the fight! All France

Now arm yourself! Your honor is suspended,

The crown and the palladium expended.

Set all your blood and all your life at stake!

Free must she be before the day is ended!

(They depart.)

A Watch Tower with an opening above.

\section{NINTH SCENE}

\section{Johanna and Lionel}

FASTOLF (entering hastily).

The people can no longer be restrained.

In fury they demand the Maid must die.

3325

Resistance is in vain. Put her to death

And throw her head down from this tower's top!

Her flowing blood alone will soothe the horde.

ISABEAU (comes).

They're laying ladders on. They storm the walis.

Come, satiate the mob! Will you still wait

3330

Until in blind rage they overturn

The tower totally and all shall perish?

You can not now protect her, give her up!

\section{LIONEL}

Let them attack! Let them in fury rage!

This castle's firm, and underneath its ruins

3335

I'll bury me, before their will prevails.

Reply to me, Johanna! Be thou mine,

And I'll protect thee, e'en against a world.

\section{ISABEAU}

Are you a man?

\section{LIONEL}

Rejected thou hast been

By thine own folk; art free of every duty 3340

To thine unworthy fatherland! The cowards, Who wooed thee once, have now forsaken thee.

They dared not wager battle for thine honor.

But I, against thy people and my own,

Stand up for thee.-Thou once didst let me think 
My life was dear to thee! And at that time I stood as foe opposed to thee in battle, And now thou hast no friend but me!

\section{JOHANNA}

Thou art

To me a foe, one hated by my people.

'Twixt thee and me there can be naught in common.

I cannot love thee, but if still thy heart

Inclines to me, then let it bring a blessing

To both our peoples: Lead thy troops away,

From off the soil of my dear fatherland,

The keys of all the cities you've subdued

Give back to us, make good all depredations,

3355

Set all our prisoners free, send hostages

As sign of sacred treaty, then to thee

I'll offer peace, and in my monarch's name.

\section{ISABEAU}

Wilt thou, in shackles, set up laws for us?

\section{JOHANNA}

Do it betimes, for thou in time must do it. France will never England's fetters carry. No, never shall that happen! Sooner will It be a vasty grave for all thine hosts.

The best of all thine heroes now have fallen; 3365

Think on thy safe return! Thy fame, forsooth, Is surely lost and all thy power gone.

ISABEAU

Can you endure this raving girl's defiance?

\section{TENTH SCENE}

A Captain enters in haste.

\section{CAPTAIN}

Haste, General, haste! Array your host for battle!

The Franks are moving up with flying banners, And all the valley glistens with their arms.

\section{JoHANNA (enthused).}

The Franks are moving up! Now, haughty England, Into the field! One now must fight with fervor! 


\section{FASTOLF}

Oh, witless woman, moderate thy joy!

Thou wilt not see the ending of this day.

\section{JOHANNA}

My folk will triumph and I shall succumb.

My valiant comrades need my arm no more.

\section{LIONEL}

I scoff at all these weaklings for we have

In twenty battles scared them on before us

Before this hero-maiden fought for them.

3380

The total nation I despise-save one

And that one they have banished. Come, Fastolf!

We will prepare for them a second day,

As that at Crecy and at Poitiers was.

You, Queen, remain here in this tower, and guard

3385

The Maiden till the contest is decided.

I'll leave you fifty horsemen for protection.

\section{FASTOLF}

What? Shall we march to meet the enemy

And leave this raging woman in our rear?

A fettered maid affrights thee?

\section{JOHANNA}

LIONEL

Give to me

Thy word, Johanna, not to free thyself!

$$
\text { JOHANNA }
$$

To free me is my one, my only wish.

\section{ISABEAU}

Put on her threefold chains! And I shall pledge My life that she shall not escape from us.

(She is fettered with heavy chains around her body and arms.)

LIONEL (to Johanna).

Thou willst it thus! Compellest us! It rests with thee! 3395; Renounce this France! And carry England's banner, And thou art free, and all these raving foes, Who now demand thy blood, shall serve thy will!

FASTOLF

Away, away, my General! 


\section{JOHANNA}

Spare thy words!

The Franks are moving up, defend thyself!

3400

(Trumpets resound. Lionel hastens away.)

FASTOLF

You know what you now have to do, my Queen!

If luck declares itself against us, if

You see our people fleeing-

ISABEAU (drawing a dagger)

Have no care!

She shall not live to witness our defeat.

FASTolF (to Johanna).

Thou knowest what awaits thee. Now implore

3405

Good fortune for thy people's arms! (He departs.)

\section{ELEVENTH SCENE}

Isabeau. Johanna. Soldiers.

JOHANNA

In that no one shall hinder me.-But hark!

That is my nation's battle march! How stirring

It echoes in my heart, presaging triumph!

Destruction unto England! Triumph France!

3410

Arise, my valiants! Up! The Maid is close

To you. She cannot, as of yore, unfurl her flag

Before you.-Heavy chains now fetter her.

But free from out her prison soars her soul

Upon the pinions of your martial song.

3415

ISABEAU (to a soldier).

Climb up the tower there, that looks toward

The field, and tell us how the fight is going.

(Soldier climbs up.)

JOHANNA

Be brave, my people! 'Tis the final fight!

Just this one triumph and the foe succumbs.

What dost thou see?

ISABEAU

\section{SOLDIER}

They are already met. 
A raging fighter on a Barbary steed, In tiger's skin, springs forth with armed men.

\section{JOHANNA}

That's Count Dunois! Go to it, worthy warrior! The victory is thine!

\section{SOLDIER}

Attacks the bridge.

Duke Burgundy

\section{ISABEAU}

Would that ten lances might

Embed themselves in his false heart, the traitor!

\section{SOLDIER}

Lord Fastolf gives him robust opposition.

They both dismount. They combat man to man,

The ducal forces and our warriors.

\section{ISABEAU}

The Dauphin see'st thou not? Nor recognizest

The royal emblems?

\section{SOLDIER}

Everything is mixed

In dust. And I can now distinguish nothing.

\section{JOHANNA}

Had he my eye, or if I stood up there, The smallest thing would not escape my gaze!

Wild partridges I count while they're in flight, 3435

And recognize the falcon high aloft.

\section{SOLDIER}

Along the moat there is a fearful throng.

The chiefs, it seems, the princes, combat there.

\section{ISABEAU}

Waves our banner still?

\section{SOLDIER}

It flies on high.

\section{JOHANNA}

Could I but peer through fissures in the wall,

I would control the conflict with my gaze!

SOLDIER

Woe's me! What do I see? Our general is

Surrounded! 
ISABEAU (draws her dagger on Johanna).

Die, unhappy wench!

SOLDIER (quickly).

He's freed.

The gallant Fastolf from the rear attacks

The foe, and breaks into his serried host.

3445

ISABEAU (withdraws her dagger).

There spoke thine angel!

\title{
SOLDIER
}

Victory! They flee!

Who flees?

\section{ISABEAU}

\section{SOLDIER}

The French and those from Burgundy,

And all the field with fugitives is covered.

$$
\text { JoHANNA }
$$

My God! so sorely wilt thou not forsake me!

\section{SOLDIER}

One gravely wounded they are leading off. Much people spring to aid him. It's a prince.

\section{ISABEAU}

One of our own or one of those of France?

\section{SOLDIER}

They loose his helmet. It is Count Dunois.

JOHANNA

(grasps at her chains with spasmodic exertion).

And I am nothing but a fettered woman!

\section{SOLDIER}

Lo! Wait! Who wears the sky-blue mantle trimmed With gold?

\author{
JOHANNA \\ It is my lord; it is my king! \\ SOLDIER
}

His steed is shy-it somersaults-it falls.

He writhes and, struggling hard, stands up again-

(Johanna accompanies these words with violent gestures.)

Our forces now approach in full career-

They now have reached him-now encircle him- 


\section{JOHANNA}

Oh has the Heaven no more angels left?

ISABEAU

Now is the time! Now, saviour, save thyself!

\section{JOHANNA}

(falls to her knees, praying with a violently irascible voice).

Hear me, Oh God, in my extremest need!

In fervent, suppliant wish, to thee on high,

Up to thy Heavens, I do send my soul.

Thou canst the fibrils of a spider's web

Make strong as hawsers holding fast a ship.

For thine omnipotence it's naught to change

These iron bonds into thin spider-webs-

But will it and these chains will fall from me,

This tower's wall will rend itself. Thou didst

Send help to Samson, when both blind and chained,

He bore the bitter scorn of his proud foes-

Then placing all his confidence in thee,

He grasped with might the pillars of his prison,

And bowed him low and plunged the structure down-

SOLDIER

Oh triumph! Triumph!

ISABEAU

What is that?

SOLDIER

Is captured!

The King

JOHANNA (springs up).

God grant me Thy grace!

(She has seized her chains violently with both hands and broken them asunder. In the same moment she throws herself on the soldier standing nearest to her, wrenches his sword from him and hastens away. All stare at her in rigid astonishment.)

\section{TWELFTH SCENE}

The preceding characters without Johanna.

ISABEAU (after a long pause).

What was that? Did I dream? Where did she go? 
How did she break this hundred-weight of bonds?

3480

For all the world I never would believe it,

Had I not seen it with my very eyes.

SOLDIER (on the watch-tower).

What? Has she wings? Or has a storm-wind carried Her quite away?

\section{ISABEAU}

Is she down there?

\section{SOLDIER}

She strides

Amid the combatants-her course is quicker

3485

Than is my sight-and now she's here, now there-

I see her at one time in many places!

She splits the hosts-and all fall back before her.

The Franks now halt and take their stand anew!

Woe's me! What's this I see? Our people throw

3490

Their weapon from them, and our banners sink-

ISABEAU

What? Will she snatch sure victory from our grasp?

\section{SOLDIER}

She presses onward straight toward the King.

She has attained him-drags him from the fight.

Lord Fastolf falls-our general has been captured.

\section{ISABEAU}

I will no longer listen. Come down here!

\section{SOLDIER}

Oh, flee, my Queen, for now you are attacked.

An arméd troop is pressing to the tower.

(He descends from the tower).

ISABEAU (drawing her sword).

Then fight, you ninnies!

\section{THIRTEENTH SCENE}

La Hire enters with soldiers. Upon his entry the soldiers of the Queen lay down their weapons.

LA HIRE (approaches her respectfully). Queen, submit yourself

To the almighty. Since your knights have all 3500 Surrendered, all resistance is in vain! 
Accept my services, and order me

To where you will be ushered.

\section{ISABEAU}

Any place,

It's all the same, where I won't meet the Dauphin.

(Surrenders her sword and follows him with the soldiers.)

The Scene changes to the Battle-field.

\section{FOURTEENTH SCENE}

Soldiers with flying banners fill the background. In front of them the King and the Duke of Burgundy. In the arms of the two princes lies Johanna mortally wounded, giving no sign of life. They walk slowly to the front of the stage.

Agnes Sorel rushes in.

SOREL (throws herself on the King's bosom.)

You are now freed-You live-Again I have you.

3505

KING

I'm free-I am, but only at this price!

(points to Johanna).

SOREL

Johanna! God! She dies!

\section{BURGUNDY}

Yes, she has finished!

Behold an angel passing! See how she there lies,

Both calm and pain-free like a sleeping child!

The peace of Heaven plays about her features,

3510

No breathing lifts her bosom any more,

But life can still be felt in her warm hand.

\section{KING}

She's gone-She never will awaken more.

Her eye will nevermore behold what's earthly.

E'en now she floats on high, a radiant spirit,

She sees no more our pain, nor our repentance.

SOREL

She opens wide her eyes! She lives!

BURGUNDY (astonished).

Comes back 
To us from out the grave? She conquers death?

She rises up! She stands!

\section{JOHANNA}

(stands quite erect and looks around).

$$
\text { Oh, where am I? }
$$

\section{BURGUNDY}

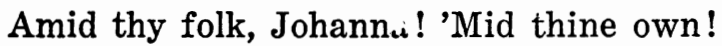

KING

Held in thy friends', yea, in thy monarch's arms!

JOHANNA

(after she has looked at him long and fixedly).

No, I am not a sorceress. Indeed

I'm not.

\section{KING}

Thou art as holy as the angels,

But our eyes were with dark night bedecked.

JoHANNA (looks around smiling cheerfully).

And I am really now among my folk, 3525 And am no more rejected and despised?

They curse me not, they look on me with kindness?

-Yes, now I recognize all things quite clearly!

That is my King! and those are France's banners!

But mine own banner see I not.-Where is it?

3530

Without my banner I dare not arrive.

It was entrusted to me by my Master,

And I must lay it down before his throne.

I dare display it, for I bore it true.

KING (with averted countenance). ${ }^{1}$

Give her the banner!

3535

(The banner is handed to her. She stands erect entirely without assistance, the banner in her hand. The heavens are illuminated by a rose-colored light.)

\section{JOHANNA}

Do you behold the rainbow in the sky?

There Heaven opens wide its golden gates

1. He gives the command to his men in a subdued voice so as not to interrupt Johanna's touching and solemn words. 
Amidst the choir of angels she radiant stands.

She holds her Son eternal to her breast,

And smiling stretches out her arms to me.

What comes o'er me? Light clouds bear me on high-

My coat-of-mail's a winged garb of feather,

And upward-upward-Earth doth backward fly-

Short is all pain, and joy endures forever!

(The banner falls from her hand. She sinks down upon it in death.-All stand for a long time in speechless emotion. Upon a quiet gesture from the King all banners are laid gently over her, so that she is completely covered by them.)

\section{UNIVERSITY OF NORTH CAROLINA STUDIES IN THE GERMANIC LANGUAGES AND LITERATURES}

1. Herbert W. Reichert. THE BASIC CONCEPTS IN THE PHILOSOPHY OF GOTTFRIED KELLER. 1949. Pp. 164 . Paper $\$ 3.00$.

2. Olga Marx ad Ernst Morwitz. THE WORKS OF STEFAN GEORGE. Rendered into English. 1949.

3. Paul H. Curts. HEROD AND MARIAMNE, A Tragedy in Five Acts by Friedrich Hebbel, Translated in English Verse. 1950. Pp. 96. Cloth $\$ 3.00$

4. Frederic E. Coenen. FRANZ GRILlParzer'S PORTRAItURE OF MEN. 1951. Pp. xii, 135. Cloth $\$ 3.50$.

5. Edwin H. Zeydel and B. Q. Morgan. THE PAKzIVAL OF WOLFRAM VON ESCHENBACH. Translated into English Verse, with Introductions, Notes, and Connecting Summaries. 1951, 1956, 1960. Pp. xii, 370. Paper $\$ 4.50$.

6. James C. O'Flaherty. UNITY AND LANGUAGE: A STUDY IN THE PHILOSOPHY OF JOHANN GEORG HAMANN. 1952. Out of print.

7. Sten G. Flygt. FRIEDRICH HEBBEL'S CONCEPTION OF MOVEMENT IN THE ABSOLUTE AND IN HISTORY. 1952.

8. Richard Kuehnemund. ARMINIUS OR THE RISE OF A NATIONAL SYMBOL. (From Hutten to Grabbe.) 1953. Pp. xxx, 122. Cloth $\$ 3.50$.

9. Lawrence S. Thompson. WILHELM WAIBLINGER IN ITALY. 1953. Pp. ix, 105. Paper $\$ 3.00$.

10. Frederick Hiebel. NOVALIS GERMAN POET - EUROPEAN THINKER - CHRISTIAN MYSTIC. 1954. Pp. xii, 126. 2nd revised edition, 1959. Paper $\$ 3.50$.

11. Walter Silz. Realism and Reality: Studies in the German Novelle of Poetic Realism. 1954. Pp. xiv, 168. Paper $\$ 4.00$.

12. Percy Matenko. LUDWIG TIECK AND AMERIKA: 1954.

13. Wilhelm Dilthey. THE ESSENCE OF PHILOSOPHY. Rendered into English by Stephen A. Emery and William T. Emery. 1954, 1961. Pp. xii, 78. \$1.50.

14. Edwin H. Zeydel and B. Q. Morgan. GREGORIUS. A Medieval Oedipus Legend by Hartmann von Aue. Translated in Rhyming Couplets with Introduction and Notes. 1955. Pp. xii, 143. Paper $\$ 3.00$ Cloth $\$ 4.00$ 



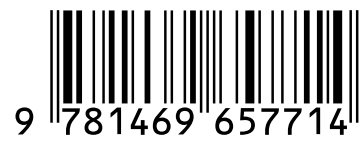

